\title{
DA PESSOA JURÍDICA NO DIREITO ROMANO*
}

\author{
THE LEGAL ENTITY IN ROMAN LAW
}

Austréia Magalhães Candido**

\begin{abstract}
Resumo:
Conceber a pessoa jurídica como sujeito de direitos ao lado do ser humano sempre foi motivo de discussão na doutrina que, por inúmeras teorias, procurou desvendar a natureza do ente moral, empreitada que até hoje não atingiu um resultado satisfatório. Assim sendo, o presente artigo pretende analisar a questão sob o prisma do Direito Romano, observando a principal característica das pessoas jurídicas, a saber, a sua distinção em relação aos seus componentes. Para isso, analisar-se-á o desenvolvimento da concepção abstrata do ente moral na disciplina romana, tendose por base, principalmente, o tratamento singular do assunto na obra de R. Orestano.
\end{abstract}

Palavras-Chave: Universitas. Pessoa Jurídica. Direito Subjetivo.

\begin{abstract}
:
Conceiving legal entities as a subject of legal entitlements alongside humans has always been a discussion on the doctrine which, through numerous theories, sought to discover the nature of the moral agent, something which to this day has yet to reach a satisfactory result. As such, this article aims to analyze the issue through the prism of Roman law, noting the main feature of legal entities, namely, the distinction in relation to its components and members. In order to achieve this, the article will analyze the development of the abstract conception of the moral agent in the Roman discipline, and was based, primarily, in the unique light the subject is presented in the work of R. Orestano.
\end{abstract}

Keywords: Universitas. Legal Entity. Subjective Right.

1. Introdução

A temática da pessoa jurídica ou ente moral sempre foi muito debatida, pois, sendo o Direito uma ciência cuja base é o ser humano, houve e ainda há uma dificuldade em aceitar e compreender como entes não humanos podem ser considerados sujeitos de direito, algo que, a princípio, só poderia ser aplicável ao homem, pois é ser dotado de vontade.

Este artigo representa parte de trabalho apresentado como Tese de Láurea, sob orientação do Professor Eduardo Cesar Silveira Vita Marchi, titular de Direito Romano da Faculdade de Direito da Universidade de São Paulo, cuja pesquisa inicial recebeu apoio do Banco Santander, mediante participação no PIC/USP (Programa de Iniciação Científica da Universidade de São Paulo) e foi laureado com o prêmio Jovem Jurista.

. Aluna do Curso de Graduação da Faculdade de Direito da Universidade de São Paulo. E-mail: austreia@, usp.br 
Daí o surgimento de inúmeras teorias, principalmente na doutrina alemã, acerca da natureza dos entes morais, não alcançando, porém, nenhuma delas, uma resposta satisfatória à pergunta o que é, afinal, a pessoa jurídica?

Costuma-se estudar tal assunto a partir do surgimento do Direito Canônico, pois seria neste período que se configuraria o ente moral como pessoa. Entretanto, dizer que a pessoa jurídica é pessoa, principalmente pela difusão da teoria da ficção, não resolve todos os nossos problemas, não sendo à toa que hoje, fenômenos como a desconsideração da personalidade jurídica e a formação de pessoas jurídicas de segundo grau, fazem com que se fale da crise do instituto da pessoa jurídica.

Sendo assim, voltaremos ainda mais no tempo, e analisaremos a configuração do tema no Direito Romano o qual, como se sabe, é o fundamento do Direito Civil nos países que adotam o sistema da Civil Law.

E observaremos, neste artigo, a principal característica das pessoas jurídicas, isto é, a sua independência com relação aos membros que a compõem.

Para isso, veremos, inicialmente, a aplicação do termo persona nas fontes romanas, para, em seguida, percorrer o caminho trilhado por um dos principais estudiosos do tema, R. Orestano, cujo tratamento singular do assunto, com a idéia da presença de fases rumo à desmaterialização, tem de ser conhecido. Por fim, analisaremos o principal fragmento concernente ao tema, Ulp. 10 ad ed., D. 3,4,7,1, sempre invocado para o estudo dessa questão.

\section{Utilização do vocábulo Persona no Direito Romano}

Podemos nos referir a qualquer ordenamento jurídico sem mencionarmos categorias como a de direito subjetivo e dever jurídico, pois os ordenamentos apenas proíbem ou obrigam certos comportamentos. Somente usamos estes conceitos quando um ordenamento coloca um sujeito de frente com outros, implicando poder e dever entre eles, se confundindo com eles mesmos. ${ }^{2}$

Sendo o Direito uma disciplina que se refere ao homem e, sendo suas características principais a inteligência e a vontade, para que ele possa se referir a outros entes tem de igualá-los ao homem, a uma figura antropomórfica capaz de entender e de querer, sendo isso o que foi feito com as pessoas jurídicas. ${ }^{3}$

1 Tal expressão é de LAMARTINE CORRÊA DE OLIVEIRA, José. A dupla crise da pessoa juridica. São Paulo: Saraiva, 1979.

2 PEROZZI, Silvio. Istituzioni di diritto romano. 2. ed. Roma: Atheneum, 1928, v. 1. p. 546-565.

3 Id. Ibid., p. 565. 
Daí a crítica feita por A. Guarino quanto à oposição entre pessoa física e pessoa jurídica, considerando errônea até mesmo a adoção da nomenclatura pessoa jurídica ou ente moral, já que tanto as pessoas físicas como as jurídicas não passam de institutos jurídicos, ${ }^{4}$

4 É interessante observar a construção lingüística do conceito de pessoa jurídica realizada por D’ALESSANDRO, Floriano. Persone Giuridiche e Analisi del Linguaggio. Padova: CEDAM, 1989. p.85122. Acompanhemos o raciocínio do Autor: faz parte do senso comum o alojamento do homem no campo individual e das corporações no campo coletivo, sendo essa alocação o grande problema das chamadas universitas personarum. Há, portanto, uma contraposição entre indivíduos simples e indivíduos compostos (coletividade unitária). O Autor, neste contexto, pretende analisar essa contraposição entre unidade e pluralidade, não no campo ontológico, mas no campo lógico-linguístico. Sendo assim, quando falamos em unidade, em coletividade ou pluralidade, não nos referimos ao ser, à essência do objeto, mas a um modo de considerá-lo dentro de certo discurso, de certa linguagem. Logo, dizer que algo é simples ou complexo depende do ponto de vista de quem o está dizendo, sendo essa classificação puramente convencional e, portanto, relativa. O Autor exemplifica: no âmbito dos sujeitos de direito, temos como unidade mínima o homem. Todavia, esse homem, considerado como unidade, é composto de milhares de células, que atuam e se modificam. Além disso, um homem pode perder algum de seus membros sem deixar de ser o mesmo homem, assim como modificar suas orientações políticas sem modificar a sua unidade. E o mesmo discurso é aplicável às pessoas jurídicas que continuam a serem as mesmas, ainda que seus membros se modifiquem. Desta forma, a individualidade não é uma qualidade inata ao homem, mas puramente convencional. O que ocorre é que habitualmente nos acostumamos a encarar o homem como uma unidade, assim como vemos a pessoa jurídica como a união entre dois ou mais homens, constituindo uma unidade destacada destes. Para o Autor, o elemento unificador, que possibilitou vermos algumas coletividades de forma individual, como sujeito de direitos, foi a criação de um nome para elas, possibilitando a visualização de um símbolo, que poderia ser trabalhado de forma independente. Esse nome foi exatamente universitas. A importância da atribuição do nome para o surgimento de um novo ente estaria evidente em Pompônio (O Autor indica o seguinte texto D. 30,41,3, todavia, ele não corresponde ao texto de Pompônio, mas ao de Ulpiano 21 ad Sab., o texto correto é D. $41,3,30$.) e em Ugolino, que afirma Universitas est plurium collectio inter se distantium uno nomine specialiter eis deputato. O problema da contraposição entre indivíduos e pessoas jurídicas é uma questão de análise entre realidade e símbolo, isto é, entre o símbolo e o simbolizado. A pergunta que o Autor se faz é se os símbolos complexos, que são definidos pelo seu uso, são símbolos incompletos, pois não definíveis além de seu uso. A idéia de que também a individualidade é relativa não oferece bases seguras para definir a existência ou não de certo objeto, sendo que neste caminho não é possível afirmar a existência dos indivíduos e a inexistência dos entes coletivos. O que, de fato, ocorre é que dentro de um discurso existem elementos unitários que nunca são analisados ou questionados, sendo unidades consideradas como ponto de partida para aquele discurso. Essas unidades fazem parte do nível individual, o mais elementar de qualquer linguagem. Todos os demais níveis (nível superior de linguagem) ou símbolos são mais complexos, porém reduzíveis àquelas unidades do nível elementar, não são relacionados, diretamente com um objeto da realidade. Assim, poderíamos dizer, em uma primeira impressão, que as proposições de nível superior são sempre dispensáveis, pois não são necessárias para descrever o mundo, atuando simplesmente como símbolos de outros símbolos (nível elementar) e não como símbolos da realidade. Visto isso, percebe-se que é possível tornar um símbolo ambiguo na medida em que podemos atribuir-lhe tanto um significado sintático como um semântico, dotando-o de dois critérios de classificação. O significado sintático de símbolos de nível superior é que esses símbolos são sempre reduziveis a elementos do nível elementar, não designando novos objetos do mundo, mas sendo apenas um modo diverso, mais sucinto, de falar de objetos do nível elementar. Já o significado semântico considera o símbolo complexo não como reduzível a unidades elementares, mas como indicador de entes individuais, isto é, o símbolo de nível superior indica diretamente um ente unitário, ainda que relativo, mas que não será analisado em sua composição, tal como os símbolos de nível elementar. A contradição que ocorre é que o mesmo símbolo, numa mesma linguagem será interpretado de duas maneiras opostas, o que não seria possível em um discurso lógico, podendo levar a resultados diversos. Neste modo de encarar a pessoa jurídica, poderíamos afirmar que encará-la como pluralidade é conferir-lhe o significado sintático e vê-la como unidade, seria dar-lhe o significado semântico. Para a resolução deste problema, alguns consideram que a pessoa jurídica é um símbolo incompleto e que, portanto, não é necessário, do ponto de vista sintático, pois é um símbolo sem significado. 
sugerindo, pois, o uso da expressão sujeito jurídico imaterial. ${ }^{5}$

Muitas dúvidas aparecem quanto ao real significado do termo pessoa nas

fontes romanas.

Neste ponto, o Autor entra na idéia do princípio da concessão nominalista, na qual a pessoa jurídica, ou melhor, seu símbolo, não faz ius a participar das coisas realmente existentes no mundo. A aplicação destes mecanismos de linguagem seria válida para qualquer símbolo complexo, não só para o complexo de coisas (universitas rerum), mas também para a pessoa jurídica (universitas personarum). Todavia, é preciso atentar para a função dos símbolos complexos, no caso, da pessoa jurídica. Não há aqui a função de representar algo existente no mundo, mas de apenas facilitar a organização do discurso, condensá-lo, o que seria muito difícil caso nos referíssemos somente aos indivíduos do nível elementar. Sendo assim, só é aceitável a contraposição entre pessoa física (átomo) e jurídica (molécula) na linguagem jurídica verbalizada, pois na realidade de fato somente o ser humano é sujeito de direitos. A pessoa jurídica é apenas um nome, somente relevante juridicamente se analisada no plano da linguagem, pois ela não é uma coisa, é somente um símbolo, uma metalinguagem, pois é símbolo de outro símbolo. Essa análise, ou seja, a adoção da tese nominalista, esclarece muitas dúvidas a respeito do que seja a pessoa jurídica, salvando-nos de teorias obscuras como a dos entes imateriais, da pessoa fictícia, centro de imputação etc. A dificuldade que se impõe à teoria nominalista é a idéia de distinção entre a pessoa jurídica e seus membros, fazendo-se necessário o recurso ao critério semântico ao lado do sintático, algo que essa teoria considera como ambíguo. Podemos dividir, no âmbito lingǘstico, em duas partes este problema. De um lado temos aquilo que é imputado à pessoa jurídica (elemento material), do outro temos a identificação daquilo (elemento pessoal) a quem imputamos alguma coisa. O Autor só tratará do segundo problema, cuja tendência é acolhermos o critério semântico e pormos lado a lado a pessoa jurídica com a pessoa física, como sujeito de direitos. O interessante é que, mesmo adotando-se o critério semântico, não temos respostas para quem pode dispor dos direitos da pessoa jurídica, ou quem deve cumprir as obrigações, entre outras. Há muito em comum, apesar da doutrina não o reconhecer, entre as questões de grupos de pessoas co-titulares de direitos e as pessoas jurídicas, pois apesar destas últimas serem destacadas de seus integrantes, nos dois agrupamentos, não há a identificação imediata do elemento pessoal de seu comportamento e a resolução de seus problemas não busca saber se há uma titularidade de quota ideal ou uma titularidade destacada das pessoas que compõem o ente, tratando-se de um problema de direito positivo. Ao invés de adentrar por esse caminho tortuoso, talvez fosse melhor abandonar o critério semântico, todavia, para isso, ter-se-ia que definir o que é uma pessoa jurídica, sendo essa definição convencionada como único modo de resolver esse problema. Ainda, pois, continuamos com a questão que é a principal característica da pessoa jurídica, a de ser um ente diverso, cuja posição jurídica não pode ser reduzida à posição dos individuos que a compõem, sendo impossível, linguisticamente, decompor o símbolo complexo em unidades do nível elementar. Para o Autor, todavia, essa dificuldade implica em circularidade. Isso porque para se dizer que é necessária a definição da pessoa jurídica, pois a que se tem é incompleta, é necessário que previamente já se tenha atribuído um significado, uma definição a este ente, pois, caso contrário, não se poderia dizer que o que se tem é incompleto, ou seja, o significado seria alcançável de outro modo, para poder se criticar a definição em uso. Logo, aquilo que vem imputado à pessoa jurídica não determina seu elemento material. Isto é. dizer que a pessoa jurídica ocupa a posição $\mathrm{X}$ é derivação de normas internas que dizem quando a pessoa jurídica estará na posição $\mathrm{X}$, ou quando um ou outro órgão se encontrará na posição Y ou Z. Neste sentido, não é necessária a busca do elemento pessoal que está dentro da pessoa jurídica. Na verdade, a posição $\mathrm{X}$ (sujeito de direitos) só serve de nexo teórico para agrupar certos fatos juridicos cujos efeitos produzem a posição individual $Y$ e $Z$. Sendo assim, não há contraposição entre pessoas físicas de um lado e jurídicas de outro. Não se trata de discursos diversos, mas de um mesmo discurso, sendo inútil a contraposição entre as obrigações da pessoa jurídica e de seus membros. O círculo vicioso se dá porque se busca um sujeito para uma relação, todavia, a existência da relação é posta em questão quando falta um sujeito. Portanto, não se pode dizer que uma teoria clara como a nominalista é inadequada, só porque é incongruente com a teoria semântica, teoria esta que é incapaz de resolver o problema sozinha.

5 Diritto Privato Romano. 12. ed. Napoli: Jovene, 2001. p. 304. 
Para alguns, o vocábulo persona já era, em época clássica, utilizado em sentido técnico pelos juristas romanos, referindo - se ao ser humano. ${ }^{6}$

No entanto, essa visão não é a única, pois estudiosos como G. Impallomeni, por outro lado, sustentam que o Direito Romano nunca atribuiu o termo persona àqueles entes abstratos que hoje denominamos pessoa jurídica. O vocábulo teria sido utilizado somente para designar o ser humano.?

Isso porque os romanos procuravam sempre evitar a utilização de termos genéricos e preferiam designar cada fenômeno jurídico de forma particularizada. ${ }^{8}$ Não obstante, há a introdução do termo universitas, no período clássico, denominação amplamente usufruída, principalmente em época justinianéia. ${ }^{9}$

O Autor faz a ressalva de que na linguagem extrajurídica, o termo pessoa era utilizado para designar as corporações públicas, mas que, todavia, tal nomenclatura não foi desenvolvida no plano jurídico.

A este termo se contrapõe a palavra homo,${ }^{10}$ que indica os servos, ${ }^{11}$ sendo o vocábulo pessoa utilizado de forma mais abstrata e, pois, abrangente, incluindo homens, mulheres, enfim o ser humano, o que representaria uma metáfora, já que o termo também tinha o significado de máscara teatral, do papel representado no teatro, o que se aplicaria às diferenças encontradas de um ser humano para outro. ${ }^{12}$

P. Catalano esclarece que a passagem de Ermogeniano (Cum igitur hominum causa omne ius constitutum sit) não se refere à sociedade, mas a uma pluralidade de homines. ${ }^{13}$

Interessante é observar que os escravos eram considerados como sujeitos de direito no Direito Romano, pois eles participavam em várias esferas do ius. Eles participavam inclusive dos collegia e não só dos religiosos, mas também dos profissionais. ${ }^{14}$

6 ALBANESE, Bernardo. Persona (storia) - Diritto Romano. Enciclopedia del Diritto. Milano:Giuffrè, 1983. v. XXXIII. p.169.

7 Persona Giuridica - Diritto Romano. Novissimo Digesto Italiano. Torino: UTET, 1965. v. XII .p. 1.029.

8 Daí a famosa assertiva de Iav. 11 epist., D. 50, 17, 202. Omnis definitio in iure civili periculosa est: parum est enim, ut non subverti posset.

9 Id. Ibid.

10 Por esse motivo consideramos a visão de Bernardo Albanese mais apropriada, pois na contraposição entre homo e persona, já há uma diferenciação jurídica, ainda que tênue, no que se refere à capacidade de direito de um e de outro.

11 Alguns fragmentos das Institutas de Gaio são citados por Bernardo Albanese, em geral, tratam sobre a aquisição de escravos como Gai. 1,119; 2,24; 2,$193 ; 4,16 ; 4,36 ; 4,40 ; 4,93 ; 4,160$.

12 Cfr. ALBANESE, Bernardo. op. cit., p. 170.

13 As raízes do problema da pessoa jurídica. Revista de Direito Civil, Imobiliário e Empresarial, São Paulo, 1995. v. 73. p. 41 .

14 Id. Ibid., p.41 e 42. É interessante observar que a colocação dos escravos como sujeitos de direito é singular na medida em que a doutrina, em geral, classifica-os como res e não como titulares de direitos e obrigações, para isso, cfr., por exemplo, MOREIRA ALVES, José Carlos. Direito Romano. Rio de Janeiro: Borsoi, 1967. v. 1; VOLTERRA, Eduardo. Istituzioni di Diritto Privato Romano. Tradução espanhola de J. Daza Martinez. 
Os conceitos de homo e de persona sempre se referiam ao homem, apesar de possuírem dimensões diversas. O termo persona era usado, em textos não jurídicos, para indicar uma coletividade de pessoas (persona civitatis e persona coloniae).$^{15}$

A divergência entre esses conceitos se inicia nos séculos V e VI, com referências aos escravos. ${ }^{16}$

Sendo assim, a idéia de pessoa como sinônima de capacidade jurídica só ocorrerá em época tardia e, mesmo assim, raramente. ${ }^{17}$

$\mathrm{O}$ início da concepção de pessoa jurídica aparece nos escritos dos agrimensores ao se referirem à persona coloniae e persona publica. ${ }^{18}$

Já o termo caput $^{19}$ se referia à própria vida das pessoas, à sua condição jurídica, como nos casos da capitis deminutio. ${ }^{20}$

R. Orestano também não atribui valor técnico ao uso do termo pessoa nas fontes romanas.

Segundo o Autor, essa tecnicidade só aparecerá em época pós clássica, ${ }^{21}$ assemelhando - se com a noção de capacidade jurídica. Todavia, mesmo em época de

Madrid: Civitas, 1991; ARANGIO-RUIZ, Vicenzo. Istituzioni di Diritto Romano. Napoli: Jovene, 2006.

15 Cfr. CATALANO, Pierangelo. op. cit., p.42.

16 Id. Ibid.

17 Cfr. ALBANESE, Bernardo. op. cit., p.170.

18 Id. Ibid.

19 BETTI, Emilio. Corso di Istituzioni di Diritto Romano. Milano: CEDAM, 1928. v. 1. p. 213, salienta que o termo caput, referia-se à personalidade da pessoa física, enquanto que o termo corpus referia-se à personalidade da pessoa jurídica.

20 Cfr. ALBANESE, Bernardo. op. cit., p.170.

2. BIONDI, Biondo. La Dottrina Giuridica della Universitas nelle Fonti Romane. Bulletino dell'Istituto di Diritto Romano Vittorio Scialoja. Milano: Giuffrè, 1958, v. XX. p. 1 - 15, critica a idéia de se tentar resolver o problema da pessoa jurídica no Direito Romano somente com a afirmação de que a doutrina da universitas seria do período justinianeu e, portanto, sem relevância para as investigações no tema. $\mathrm{Na}$ realidade, mesmo que provenientes da filosofia, como a idéia de res ex distantibus, deve-se observar em que medida esse conceito trouxe efeitos jurídicos, já que também o Direito é uma ciência que reflete os anseios da sociedade. Sendo assim, para o Autor, o termo universitas significaria tanto uma totalidade como uma unidade. O mesmo ocorreria com o uso de termos coletivos, como no caso da palavra familia a qual indica uma totalidade e o termo municipium que indica uma unidade. Aplicando-se a denominação de universitas às unidades, como o municipium e o populus, estaríamos a um passo de reconhecer-lhes a personalidade jurídica, já que não representavam a soma de seus componentes e sim algo diverso. Também diferentes seriam os usos do termo omnia em comparação com universa, o primeiro indica a soma, os componentes individuados, e o segundo a unidade destes componentes. A palavra universitas tanto indicaria uma unidade que não se confunde com seus membros, que uma associação, mesmo que reduzida a um único membro, manteria a universalidade. O mesmo se dá, futuramente, com o uso do termo corpus, o qual indica uma unidade ideal, isto é, o habere corpus. O autor ressalta que não há sobreposição de uma concepção sobre outra e um mesmo objeto pode ora ser considerado como totalidade, ora como unidade, e, para comprovar isso, dá o exemplo do dinheiro. Afinal, cem moedas utilizadas para solver um débito são consideradas como totalidade, mas se essas cem moedas forem uma coleção, temos uma unidade. O problema da análise do tema no Direito Romano estaria, pois, na necessidade da doutrina moderna de encaixar tudo em um conceito único, sem elasticidade. No entanto, a sistemática romana era diversa e, por isso, não houve uma noção única de universitas e sim uma multiplicidade de disposições, cada uma adequada para satisfazer demandas sociais diversas. 
Justiniano, o uso freqüente da palavra será sempre de forma geral, generalidade que passará pelo direito medieval e até mesmo no período do renascimento. ${ }^{22}$

Entretanto, em certos momentos, o vocábulo foi usado para situações que não se referiam ao homem de forma singular, como ocorre em Cícero. De acordo com os glosadores, porém, apesar da distinção entre universitas e seus membros, não haveria uma contraposição entre as duas figuras, não sendo considerada, pois, como pessoa. ${ }^{23}$

Somente no Direito Canônico o termo passa a ser utilizado com um sentido mais abstrato, passível de configurar uma unidade distinta de seus membros, principalmente devido à obra de Sinibaldus de Flisco. ${ }^{24}$

Desta forma, seria no século XVI, que a concepção de pessoa se apresentaria em duplo sentido, referindo-se tanto às pessoas naturais como às universitas e corpora..$^{25}$

Em geral, afirma-se que os conceitos de pessoa ou sujeito de direito é coincidente com o conceito de homem. Entretanto, modificações podem ser feitas a fim de retirar de certos homens a capacidade jurídica ou estender a seres que não são homens essa capacidade ${ }^{26}$

É neste momento que vemos paralelamente, segundo P. Catalano, o início da formação do conceito abstrato de Estado. Por consequência, a reflexão moderna acaba por construir inúmeros conceitos abstratos e, por meio da colocação de trechos das fontes romanas descontextualizados, atribuí-los aos romanos. ${ }^{27}$

Disto resulta o afastamento da noção de populus da de Estado, ente diverso dos cidadãos e a separação entre as concepções de homem e pessoa, existindo pessoas que não são homens e homens que não são pessoas, contrapondo-se, de modo incoerente na visão do Autor, por exemplo, pessoa e feto. ${ }^{28}$

Mas, mesmo com esta evolução, R. Orestano qualifica o problema da pessoa jurídica como um problema do século XIX, pois é neste momento que se desenvolve a noção subjetiva de sujeito de direito, um ser capaz de ter vontade própria, como sinônimo de pessoa, dificultando a submissão das pessoas jurídicas a esta categoria. ${ }^{29}$

Para resolver este problema, é que o debate sobre a natureza da pessoa jurídica surgiu, com a elaboração de inúmeras teorias, dentre as quais a da ficção e a da realidade. ${ }^{30}$

22 ORESTANO, Ricardo. Il problema delle persone giuridiche in diritto romano.Torino: G. Giappichelli, 1968. p. 9.

23 Id. Ibid., p.10.

24 Id. Ibid., p.11.

25 Id. Ibid., p.13.

26 Cfr. CATALANO, Pierangelo. op. cit., p. 42 e 43.

27 Id. Ibid., p. 43.

28 Id. Ibid., p. 44.

29 Cfr. ORESTANO, Riccardo. op. cit., p.18 e 19.

30 Id. Ibid., p. 20. 
O Autor critica as duas posições extremadas da doutrina, a saber, aquela que afirma a existência de pessoas jurídicas no Direito Romano tal como a entendemos hoje e aquela que sustenta exatamente o contrário, que nunca houve pessoa jurídica nem a noção de pessoa jurídica em época romana, já que mesmo que não tenham elaborado uma teoria da pessoa jurídica não deixaram sem solução ${ }^{31}$ situações resolvidas pelo uso deste instituto. ${ }^{32}$

Para B. Albanese, ${ }^{33}$ não há que se questionar a referência não jurídica da atribuição do vocábulo persona às coletividades, pois, mesmo que nunca tenha havido a elaboração de uma teoria ${ }^{34}$ sobre a pessoa jurídica, até porque, para os romanos, não havia a necessidade de elaboração teórica de conceitos simples como o de sujeito de direito e de capacidade jurídica, tidos como pressupostos da pessoa jurídica, as coletividades seriam, de certa forma, também consideradas juridicamente como pessoas. ${ }^{35}$

31 ELIACHEVITCH, Basile. La personnalité juridique en droit privé romain. Paris: Sirey, 1942, p. 327-330, afirma que se deve notar que o termo persona sempre foi referente ao ser humano, não existindo sujeitos de direitos que o substituísse. Existiam outros participantes ao seu lado, mas não eram eles pessoas, sujeitos de direitos, como a doutrina moderna as denominou. Não haveria, portanto, a criação de uma teoria, de uma concepção abstrata ou de uma nomenclatura comum. O que há é a aplicação, por analogia, de traços comuns seja aos municípios, seja aos colégios, seja às sociedades. Na mesma linha de raciocínio temos TALAMANCA, Mario Istituzioni di diritto romano. Milano: Giuffrè, 1990. p. 174-176, para quem apesar da pessoa jurídica moderna encontrar fundamento em algumas estruturas do Direito Romano, este não apresentou nenhuma nomenclatura equivalente ao sujeito de direitos que hodiernamente atua ao lado da pessoa física. A pessoa jurídica não seria, para o Autor, um fenômeno unitário. É necessária a sua análise de acordo com o aspecto sócio-econômico e com a roupagem jurídica que lhe configura. É preciso observar também que, dependendo do tipo de ente levado em consideração, será mais importante o seu aspecto patrimonial ou pessoal, sendo que o Direito Romano não conheceu o fenômeno das fundações cujo relevo é o patrimonial. O Autor ainda ressalta que não há apenas a bipolaridade, autonomia completa versus falta $\mathrm{e}$ autonomia. $\mathrm{O}$ que existe, na realidade, são diferentes graus de personificação, nos quais sempre existirá um centro de imputação que não coincide com os indivíduos que o formam.

32 Cfr. ORESTANO, Riccardo. op. cit., p.79 e 80.

33 Cfr. ALBANESE, Bernardo. op. cit., p. 180.

34 Para MAURO, Tommaso. La Personalità Giuridica degli Enti Ecclesiastici. Roma: Polighotta Vaticana, 1945 , p. 2; não há impedimento lógico para que o sistema romanista vivenciasse a disciplina dos entes imateriais, já que as pessoas que por eles agiam eram parte de um todo que delas dependia, mas que não se confundia com elas.

3s BONFANTE, Pietro. Diritto Romano. Milano: Giuffrè, 1976. p. 176, trilha caminho semelhante ao afirmar que o Direito Romano teria atribuído claramente as características e o título de pessoa a essas coletividades que não se apresentariam como meras ficções, visto que a vontade de seus membros, pelo pacto comum, seria considerada como vontade da sociedade. 
Sendo assim, havia a consideração de uma pluralidade de pessoas como um único ente, sob a denominação de corpus ${ }^{36}$ ou universitas, denominações que possuíam, na visão do Autor, o mesmo significado. ${ }^{37}$

3. Fases rumo à desmaterialização - a doutrina de R. Orestano

3.1. A noção de direito subjetivo como obstáculo ao entendimento da sistemática romana

É sempre presente a idéia de que o surgimento da sociedade se dá após o estabelecimento de um contrato entre os indivíduos, o que evidenciaria uma evolução no sentido indivíduo - sociedade. ${ }^{38}$

Todavia, na Antiguidade, essa evolução parece ocorrer em sentido contrário, isto é, inicialmente temos a figura de uma sociedade forte e, posteriormente, o indivíduo passa a ser relevante. Para comprovar isto, basta observarmos a estrutura da família romana e os primeiros tipos de propriedade, que se consolidava na figura do grupo. ${ }^{39}$

De acordo com R. Orestano, muitos estudiosos, dependendo da teoria a qual se filiam, seja a da fiç̧ão, seja a da realidade, podem considerar ou não a existência de pessoas jurídicas nestas situações logo acima mencionadas. Entretanto, haveria um obstáculo a ser transposto, que é o de enquadrar a disciplina do Direito Romano na categoria de sujeito de direito, cuja principal característica é a de possuir vontade própria, o que seria incompatível com as peculiaridades apresentadas pela regulação romana. ${ }^{40}$

\footnotetext{
36 É interessante observar a diferenciação que faz DE ROBERTIS, Francesco M. Il Diritto Associativo Romano. Bari: Laterza \& Figli, 1938, p. 17-19, entre os termos corpus, collegium, sodalicium e sodalitas. Para o Autor, tanto sodalitas quanto sodalicium significariam a mesma coisa, sendo o último menos usado que o primeiro. Já corpus e universitas seriam também equivalentes no período clássico, todavia, nos séculos IV e V, em Roma e em Bizâncio teria se preferido o uso da palavra corpus e, nas demais regiões do império, a palavra collegium.

37 Cfr. ALBANESE, Bernardo. op. cit., p. 180.

38 Tal afirmação é proveniente da difusão da doutrina contratualista, cujos principais expoentes são Thomas Hobbes, John Locke e Jean- Jacques Rosseau.

39 Cfr. ORESTANO, Riccardo. op. cit., p. 82.

40 Id. Ibid., p. 86-87.
} 
Para o Autor, a melhor alternativa é a de considerar essas situações como centros de referência de relações jurídicas, não se atribuindo nenhuma carga subjetiva ${ }^{41}$ a esse centro. ${ }^{42}$

Contudo, esse conceito não se aplicaria a uma situação específica, a da destinação de bens que não implicavam em imputação, cujos objetivos eram alcançados por via indireta e que não se assemelhavam ao que hoje temos como fundação. ${ }^{43}$

É necessário observar que os problemas referentes às pessoas jurídicas, principalmente após a época dos Severos, não é, como costuma a doutrina enfatizar, somente de representação. ${ }^{44}$

Poucas são, segundo o Autor, as fontes que relacionam estas situações diretamente à idéia de sujeito de direito e, quando isto ocorre, trata-se de uma regulação de alguma matéria especial, que é semelhante à que cabe ao homem, nunca constituindo as coletividades como sujeitos de direito paralelos ao homem. ${ }^{45}$

41 PUGLIESE, Giovanni. Res corporales, res incorporales e il problema del diritto soggetivo. Scritti Giuridici Scelti. Napoli: Jovene, 1985. v. 3, p. 226-232. O Autor tem como objetivo a crítica da afirmação sustentada por parte da doutrina de que o Direito Romano jamais conheceu a noção de direito subjetivo, colocando o sujeito como centro de referência jurídica. É considerado pacífico que o sistema romano não definiu, não conceitualizou a idéia de direito subjetivo, no entanto, como já se sabe, os romanos não trabalhavam com conceitos, pois as poucas definições encontradas nas fontes são do final da época clássica ou interpoladas. O Autor afirma que para que o estudo do Direito Romano tenha sentido, é indispensável que o estudemos não só com os elementos da época, mas com as ferramentas que nos oferece o Direito atual. Não se deveria, pois, tentar encaixar a todo custo o Direito Romano na doutrina moderna, mas por meio dela, observar e entender o Direito Romano. Sendo assim, a inexistência de um conceito não seria obstáculo à existência de um determinado instituto, sendo isso o que ocorre no caso do direito subjetivo (e também no da pessoa jurídica). Até porque, ainda hoje, não haveria, segundo o Autor, uma definição satisfatória para essa figura jurídica. Uma das teorias levantadas é que situações que chamamos hoje de subjetivas eram existentes em época romana, mas que, no entanto, não eram tratadas subjetivamente, mas objetivamente, sem a idéia de pertencer ao sujeito de direito.

44 Id. Ibid., p. 94. VOCI, Pasquale. Piccolo Manuale di diritto romano. Milano: Giuffrè, 1979. v. 1. p. 255-256, afirma que a idéia de que os atos do gestor da sociedade ou da cidade seriam atos da própria corporação ou cidade ainda teria de enfrentar várias barreiras, progredindo aos poucos. O Autor enumera três obstáculos ao progresso desta idéia, a saber, a ausência de representação direta, a imposição de que certos atos devem ser realizados pessoalmente por quem adquire (aceitação de herança), e o fato de que determinados atos ou relações jurídicas só podem se constituir e existir referindo-se a individuos, pois estes seriam capazes de ter vontade. O pretor resolveria o primeiro problema com a transferência das ações para o representante. Quanto ao segundo problema, a solução se dá por meio da autoridade imperial, pois não poderiam todos os cidadãos consentir e nem o magistrado representar as cidades. Já o terceiro ponto se refere principalmente à questão do usufruto e da posse. O uso e o fruto são dotados de pessoalidade, algo que falta às pessoas jurídicas. Todavia, os juristas teriam resolvido este problema. No que se refere à posse, como seria possivel caracterizar o animus possidendi? Cogitou-se na posse de todos os cidadãos, hipótese que se mostrou mais uma vez frustrante. Havia o recurso à aquisição por meio de escravos, funcionando a pessoa jurídica como um domino etiam ignoranti. Todavia, o problema permanecia, pois era necessário possuir também o escravo. Na prática, porém, foi reconhecida a capacidade de possuir aos entes morais. 
A divisão realizada entre fundações, como complexo de bens, e associações, como conjunto de pessoas, portanto, não corresponderia à concepção romana. ${ }^{46}$

As denominações utilizadas pelo Direito Romano para se referir às coletividades de um modo geral, ora se mostram como um substantivo ao singular como é o caso do municipium, colonia, civitas e sodalicium ora como um substantivo ao plural, indicando os integrantes desta coletividade como municipes, coloni, cives e sodales. ${ }^{47}$

Isso é o que justifica a opinião de parte da doutrina ${ }^{48}$ de que haveria uma imprecisão técnica nas denominações romanas no que se refere a este tema, pois não se pode esquecer que uma ou outra denominação implica em consequências diversas. ${ }^{49}$

É importante observar que sempre há a presença de um elemento pessoal, mesmo quando se considera um complexo de bens em si mesmo, como no caso do fisco e da herança jacente, já que sempre se apresentam como objeto de interesse humano, seja do imperador, no caso do fisco, seja de quem aceita a herança, no caso da herança jacente. ${ }^{50}$

Entretanto, esse elemento pessoal pode ser considerado em segundo plano para certas relações que são atribuídas não a homens, seja individualmente, seja coletivamente, mas a entidades materiais. ${ }^{51}$

\subsection{A idéia de nomen iuris como pressuposto da concepção material}

Desta forma, algumas relações jurídicas eram imputadas diretamente a entidades materiais, e essas entidades materiais poderiam ser constituídas de pessoas, que, em conjunto, seriam consideradas como res. O que pode soar estranho, segundo o Autor, porque estaríamos atribuindo relações jurídicas a entes que não são sujeitos de direito, mas coisas. ${ }^{52}$

O termo res indica, em sua acepção originária, apenas um elemento em particular, mas, com o passar do tempo, adquire o significado de conjunto, sendo um termo capaz de indicar situações unificadas, mesmo que os elementos deste conjunto fossem de espécies e natureza diferentes, como a contraposição res privata e res publica demonstram.

46 ORESTANO, Ricardo. Il problema delle persone giuridiche in diritto romano.Torino: G. Giappichelli, 1968. p. 101.

47 Id. Ibid., p.102.

48 Nesse sentido cfr. KASER,Max. Römisches Privatrech. Tradução portuguesa de S. Rodrigues e F. Hämmerle. Lisboa: Calouste Gulbenkian, 1999. p. 116.

49 Cfr. ORESTANO, Riccardo. op. cit., p. 102. O Autor traz como exemplo o seguinte fragmento: Marc. 3 Inst., D. 1,8,6,1, que será reproduzido ao longo deste artigo.

so Id. Ibid., p. 103 e 104.

si Id. Ibid., p. 104.

52 Id. Ibid., p. 105, 107 e 108. Um dos exemplos dados pelo Autor é o das servidões prediais que eram direitos do próprio prédio (iura praediorum) e não do proprietário. 
O termo res publica aparece nas fontes em dois sentidos diversos. O primeiro é o que se refere às comunidades de cidadãos romanos, por exemplo, na acepção de res Romana, res Latina ou res Albana. O segundo é representado simplesmente ao referimento res publica. No primeiro sentido, o termo res é utilizado para especificar a propriedade de determinado grupo. Já no segundo, mais abstrato, ele é contraposto à expressão res privata.

Numa primeira concepção, haveria a identificação da res publica com a res populi Romani, mas em Cícero, isso não significa necessariamente uma relação de propriedade, pois a res publica seria o próprio populus, sendo, neste sentido, o povo, o conjunto de cidadãos tratados como res.

Somente em época imperial, esse termo viraria sinônimo de patrimônio público, isso porque até então, o termo res seria um agregado de elementos pessoais e reais, que não se ligava somente ao aspecto patrimonial. ${ }^{53}$

Outro termo importante a ser analisado é a palavra nomen, que indica uma unidade política anterior ao surgimento de Roma.

Esse termo é frequente nas fontes romanas, principalmente sob a forma de nomen Romanum, nomen Vulscum, Etruscum, Italicum etc., significando, na visão do Autor, não somente a concepção unificada de seus elementos, mas tudo aquilo sobre o que se pode aplicar a qualificação de romano e etrusco, por exemplo. ${ }^{54}$

Assim, nomen, não é somente a palavra que designa alguma coisa, mas é a própria coisa, que se manifesta e existe por meio de seu nomen. Sendo assim, o nomen não é algo diverso daquilo que designa. Daí a afirmação de R. Orestano de que dar um nome a alguma coisa é criá - la, pois a existência do nome estaria interligada com a existência do objeto, da coisa nominada, tendo o nome um lastro material. ${ }^{55}$

Isso permitiria entender porque alguns conjuntos de pessoas e de coisas pudessem ser tratados como res, até o período do primeiro Principado.

O ponto a que o Autor quer chegar é o de como se poderia considerar um conjunto de pessoas como uma entidade material.

Sendo assim, elementos diversos entre si, como o instrumentum fundi, grex, poderiam ser tratados por meio de um nome singular como um objeto unificado, coletivo, devido a sua importância econômica e social, trazendo propriedades diferentes quando analisamos os elementos individualmente e coletivamente. ${ }^{56}$

\footnotetext{
53 ORESTANO, Ricardo. Il problema delle persone giuridiche in diritto romano. Torino: G. Giappichelli, 1968. p. 110-114.

54 Id. Ibid., p. 115.

55 Id. Ibid., p. 118.

s6 Id. Ibid., p. 119.
} 
Esses nomes unificados, já existiam desde os primórdios de Roma, bastando observar o uso de termos como populus, tribus, família, gens.

O Autor afirma que, para o Direito Romano, o conjunto é ao mesmo tempo os seus elementos integrantes e esses elementos na sua totalidade são o conjunto. Por isso, há a possibilidade de ocorrerem modificações de seus elementos, não sendo o conjunto que adquire ou perde elementos, sendo algo distinto destes, mas é o conjunto que se renova, que se modifica com o modificar de seus elementos. E é neste ponto que vemos uma diferença entre esta concepção e a idéia de pessoa jurídica moderna, pois esta é um ente totalmente distinto, inconfundível com seus elementos. ${ }^{57}$

É preciso observar que nem todas as coletividades foram tidas como centro de relações jurídicas, isto é, como res (sem uma idéia subjetivista como a pessoa jurídica moderna), como podemos conferir no caso da família romana, cujo centro de imputação sempre foi um de seus elementos, isto é, o paterfamilias. ${ }^{58}$

Quando analisamos a jurisprudência romana, percebemos que o tratamento das situações unificadas pelos juristas da época nos reporta à noção de res, acima analisada e que, posteriormente chegará à teoria dos corpora, também encarado em senso material. ${ }^{59}$

Um dos grandes problemas da análise do Corpus Iuris Civilis é que se tenta agrupar testemunhos de épocas diferentes, de fases diferentes em um todo único, o que traz dificuldades imensas para a compreensão das situações unificadas em época romana, até porque não se deve esquecer o fim que o Digesto de Justiniano tinha e o porquê da união de pareceres de juristas de épocas diferentes em um todo único. ${ }^{60}$

3.3. Primeiro Período: as situações unificadas como res - a concepção de res ex distantibus

Sendo assim, o Autor procurará analisar a evolução da disciplina destas situações unificadas.

O primeiro bloco de textos é o que se encontra entre o último século a.C e o I séc. d.C, com escritos de Alfeno, Celso, Ulpiano e Paulo comentando escritos mais antigos de Sabino e Quinto Múcio, por exemplo.

Mostra - se, aqui, as primeiras influências do pensamento estóico, filosofia grega, no Direito Romano, que já, desde o princípio, encaixava as situações unificadas na categoria de res. ${ }^{61}$

\footnotetext{
s7 ORESTANO, Ricardo. Il problema delle persone giuridiche in diritto romano.Torino: G. Giappichelli, 1968. p. 120.

58 Id. Ibid., p. 121.

59 Id. Ibid., p. 123.

60 Id. Ibid., p. 124.

61 Id. Ibid., p.125-126.
} 
O primeiro texto que, segundo o Autor, trata destas situações unificadas e que tem como pressuposta a sua colocação como res é um texto de Alfeno:

Alf. 6 dig., D. 5,1,76. Proponebatur ex his iudicibus, qui in eandem rem dati essent, nonullos causa audita excusatos esse inque eorum locum alios esse sumptos, et quaerebatur, singulorum iudicum mutatio eandem rem an aliud iudicium fecisset. Respondi, non modo si unus aut alter, sed et si omnes iudices mutati essent, tamen et rem eandem et iudicium idem quod antea fuisset permanere: neque in hoc solum evenire, ut partibus commutatis eadem res esse existimaretur, sed et in multis ceteris rebus: nam et legionem eandem haberi, ex qua multi decessissent, quorum in locum alii subiecti essent: et populum eundem hoc tempore putari qui abhinc centum annis fuissent, cum ex illis nemo nunc viveret: itemque navem, si adeo saepe refecta esset, ut nulla tabula eadem permaneret quae non nova fuisset, nihilo minus eandem navem esse existimari. Quod si quis putaret partibus commutatis aliam rem fieri, fore ut ex eius ratione nos ipsi non idem essemus qui abhinc anno fuissemus, propterea quod, ut philosophi dicerent, ex quibus particulis minimis constiteremus, hae cottidie ex nostro corpore decederent aliaeque extrinsecus in earum locum accederent. Quapropter cuius rei species eadem consisteret, rem quoque eandem esse existimari.

É apresentada [a situação] daqueles juízes, os quais foram dados [convocados] para um mesmo assunto, alguns, ouvido a causa, foram dispensados e, no lugar deles, outros foram escolhidos, e foi perguntado, se a mudança dos indivíduos do juízo para o mesmo assunto faria do juízo outro. Respondi, não só se um ou outro, mas também se todos os juízes forem mudados, no entanto, tanto o assunto como o juízo permanece o mesmo que era antes: não só acontece desta forma, quando mudadas as partes fosse considerado o assunto o mesmo, mas também em muitos outros casos: efetivamente, também se tem a mesma legião, na qual muitos morressem, cujos postos fossem substituídos por outros: e o povo é considerado o mesmo, neste tempo, que há cem anos fora, mesmo que dele ninguém agora viva: e também o navio, se frequentemente, por inteiro, fosse reparado, de forma que nenhuma mesma tábua permanecesse que não fosse nova, entretanto, se considera o mesmo navio. Por isso, se alguém considerasse que mudadas as partes outra coisa fosse feita, por esta razão nós mesmos não seríamos os mesmos que éramos há um ano, isso porque, como diziam os filósofos, daquelas partículas mínimas [das quais] somos constituídos, estas cotidianamente do nosso corpo saem e outras externas em seu lugar se colocam. Por esta razão, 
a coisa, a qual consistisse na mesma espécie, se considera também a mesma coisa. ${ }^{62}$

A questão que se põe é a de se a mudança de algum elemento constitutivo de uma res dá origem a uma res nova ou se, ao contrário, ela permanece a mesma. A resposta de Alfeno é de que a res permanece a mesma, tal como ocorre com as legiões, o povo, um barco e com o corpo humano.

O Autor ressalta a importância deste fragmento devido à ótica puramente material na qual se coloca o jurista, concluindo que apesar da mudança de seus elementos internos, a res não muda, continuando a ser denominada com um nome no singular que representa a sua totalidade, que não se modifica. Daí concluirmos que a análise da res como um conjunto unificado é sempre baseada em elementos objetivos e não subjetivos ${ }^{63}$

Neste sentido, outro fragmento de Alfeno seria de grande importância:

Alf. 3 a Paul. Epitom., D. 33, 10, 6. Supellectilis eas esse res puto, quae ad usum communem patris familias paratae essent, quae nomen sui generis separatim non haberent: quare quae ad artificii genus aliquod pertinerent neque ad communem usum patris familias accommodatae essent, supellectilis non esse.

Considero que sejam coisas do mobiliário, aquelas que para o uso comum do pater famílias se encontrem à disposição, as quais uma denominação de seu gênero isoladamente não teriam. Aquelas que pertenceriam a um gênero de arte, mas que não seriam apropriadas para o uso comum do pater famílias, do mobiliário não são. ${ }^{64}$

Nesta passagem, que trata da supellex, deixa - se claro que a unificação de elementos distintos como res era devida ao fato de que esses elementos poderiam ser abrangidos por uma mesma denominação, por um mesmo nomen, tornando esses objetos uma totalidade capaz de ser objeto de relações jurídicas de forma unitária. ${ }^{65}$

Outro passo que demonstra a importância do uso lingüístico aplicado ao Direito é o fragmento de Celso, D. 33,10,7,2, o qual afirma que é o uso corrente dos termos em uma dada sociedade, o que determina quais elementos fazem ou não parte da supellex.

\footnotetext{
Tradução livre.

Cfr. ORESTANO, Riccardo. op. cit.,p. 128.

Tradução livre.

65 Cfr. ORESTANO, Riccardo. op. cit., p. 129. Tratando do mesmo assunto o Autor ressalta os seguintes fragmentos: Paul. 75 ad ed., D. 31,2. Quotiens nominatim plures res in legato exprimuntur, plura legata sunt: si autem supellex aut argentum aut peculium aut instrumentum legatum sit, unum legatum est. Paul. $l$. sing. ad L. Falcid., D. 31, 6. Grege autem legato non potest quaedam sperni, quaedam vindicari, quia non plura, sed unum legatum est. Idemque dicemus peculio legato aut veste aut argento et similibus.
} 
Cel. 19 dig., D. 33, 10, 7, 2. Servius fatetur sententiam eius qui legaverit aspici oportere, in quam rationem ea solitus sit referre: verum si ea, de quibus non ambigeretur, quin in alieno genere essent, ut puta escarium argentum aut paenulas et togas, supellectili quis adscribere solitus sit, non idcirco existimari oportere supellectili legata ea quoque contineri: non enim ex opinionibus singulorum, sed ex communi usu nomina exaudiri debere. Id Tubero parum sibi liquere ait: nam quorsum nomina, inquit, nisi ut demonstrarent voluntatem dicentis? Equidem non arbitror quemquam dicere, quod non sentiret, ut maxime nomine usus sit, quo id appellari solet: nam vocis ministerio utimur: ceterum nemo existimandus est dixisse, quod non mente agitaverit. Sed etsi magnopere me Tuberonis et ratio et auctoritas movet, non tamen a servio dissentio non videri quemquam dixisse, cuius non suo nomine usus sit. Nam etsi prior atque potentior est quam vox mens dicentis, tamen nemo sine voce dixisse existimatur: nisi forte et eos, qui loqui non possunt, conato ipso et sono quodam kai ty anarvrw fwny [id est: voce inarticulata] dicere existimamus.

Sérvio opinou que é necessário considerar a intenção daquele que legasse, o modo pelo qual ele esteja habituado a se referir: efetivamente se aquelas [coisas] sobre as quais não se questionava, que em outro gênero estivessem, por exemplo, como a louça de prata ou pénulas e togas, as quais fosse comum atribuir ao mobiliário [enxoval], não por essa razão é necessário que se considere que elas também estão contidas no mobiliário legado: de fato, não das opiniões dos indivíduos, mas do uso comum dos nomes deve ser entendido. Isto, porque pouco claro para si, disse Túbero: na verdade, para que fim os nomes, diz ele, senão para demonstrarem a vontade dos que falam? Sem dúvida, não creio que alguém diga, aquilo que não sinta, sobretudo, quando esteja usando o nome, pelo qual se costuma chamar aquela coisa: de fato, nos servimos do recurso da voz: porém não se deve considerar que alguém tenha dito, o que não estava na mente. Mas, ainda que, me impressione muito a razão e a autoridade de Túbero, não discordo, porém, de Sérvio, pois não parece que alguém dissesse de alguma coisa se não usasse o seu nome. Efetivamente, diz ele, mais importante e mais poderoso do que a voz é o intento de quem fala, porém, ninguém sem a voz se considera que tenha falado: exceto se considerarmos que também aqueles, os quais falar não podem, eles mesmos com esforço e som tenham, de alguma maneira, [isto é: com voz inarticulada] falado. ${ }^{66}$

66 Tradução livre. 
Outro fragmento que demonstra a importância do nomen como elemento unificante é o D. 41,3,30, ${ }^{67}$ de Pompônio. Neste fragmento há uma distinção entre três tipos de corpora, a saber, aquelas que possuíssem um espírito, como o homem ou uma pedra, as ex contingentibus, formadas pela união material de vários elementos como um prédio ou um navio e, por fim, as ex distantibus, nas quais os seus diversos elementos, apesar de materialmente separados, estão unidos por um nomen como o Populus ou o grex. ${ }^{68}$ Distinção que corresponde ao que hoje chamamos de coisas simples, compostas e universais. ${ }^{69}$

\begin{abstract}
Pomp. 30 ad Sab., D. 41,3,30. Rerum mixtura facta an usucapionem cuiusque praecedentem interrumpit, quaeritur. Tria autem genera sunt corporum, unum, quod continetur uno spiritu et Graece hynwmenon [continuum] vocatur, ut homo tignum lapis et similia: alterum, quod ex contingentibus, hoc est pluribus inter se cohaerentibus constat, quod sunymmenon vocatur, ut aedificium navis armarium: tertium, quod ex distantibus constat, ut corpora plura non soluta, sed uni nomini subiecta, veluti populus legio grex. Primum genus usucapione quaestionem non habet, secundum et tertium habet.
\end{abstract}

Foi perguntado se a mistura feita das coisas interrompe a usucapião precedente de cada uma. Três, porém são os gêneros dos corpos, um, no qual é compreendido um espírito e é chamado pelos gregos de hynwmenon [unido], como o homem, o barrote, a pedra e similares: outro, o qual de componentes, isto é, de muitas [coisas] entre si unidas consiste, as quais são chamadas de sunymmenon [conexas], como um edifício, um navio, um armário: o terceiro, o qual de [coisas] distantes consiste, como muitos corpos não separados, mas sujeitos a um único nome, como o povo, a legião, o rebanho. No primeiro gênero não se põe a questão da usucapião, no segundo e no terceiro coloca-se. ${ }^{70}$

Essa distinção relaciona-se com outra, também muito importante para o tema em estudo que é a diferenciação entre res corporales e res incorporales ${ }^{71}$ que the é posterior.

O Autor critica o fato de que parte da pandectística insista em afirmar a impossibilidade do fragmento de Pompônio colocar lado a lado objetos materiais e imateriais com as res ex distantibus, sustentando que o termo corpus foi usado, no último

67 Ver também para esse assunto Paul. 21 ad ed., D.6,1,23,5. Cfr. MARKY, Thomas. Curso elementar de direito romano. São Paulo: Saraiva, 1995. p.43.

68 Cfr. ORESTANO, Ricardo. Il problema delle persone giuridiche in diritto romano. Torino: G. Giappichelli, 1968. p. 131.

69 Tratando sobre outras situações unificadas ver também Gai. 10 ad ed. Provinc., D. 18,1,35,6; Marc. l. sing. ad form. Hypoth., D. 20,1,13; Scaev. 27 dig., D. 20,1,34; Afr. 6 quaest., D. 21,1,34.

70 Tradução livre.

71 Cfr. ORESTANO, Riccardo. op. cit., p. 132. 
caso, em sentido abstrato e apenas por conveniência, para indicar uma série de relações que se referissem a essas coisas. ${ }^{72}$

Outra crítica feita pelo Autor é contra a afirmação de que o termo corpus jamais seria equivalente a res, pois se assim fosse, estaríamos considerando homens livres como res e, além disso, a expressão corpus ex distantibus não poderia se referir às coisas coletivas, pois, ora se referiria a objetos, ora a sujeitos de direito, o que seria contraditório.

Para R. Orestano isso seria uma contaminação do pensamento subjetivista moderno na análise de institutos passados, com a divisão intransponível entre sujeito e objeto de direito.

É inegável que Pompônio nunca se referiu a homens livres diretamente como res (apesar de nas XII Tábuas se colocar o corpo do devedor como objeto da obrigação ${ }^{73}$ ). Todavia, quando o ponto de referência não era o homem individualmente, mas uma associação de homens, sejam eles livres ou não, as fontes os tratavam como corpora (as quais, na maior parte, mas nem sempre, tinham caráter público e personalidade jurídica) e as corpora, em certas hipóteses, eram tratadas como res. ${ }^{74}$

Apesar de não haver nenhum texto que trate das res ex distantibus, a contraposição entre os textos que falam de res e os de corpus ex distantibus demonstram que os mesmos exemplos usados para um são usados para outro. ${ }^{75}$

Para qualificar as corpora ex distantibus, Pompônio utiliza a expressão uni nomini subiecta e Sêneca a expressão iure aut officio cohaerent.

Não se pode dizer, segundo o Autor, que a linguagem de Pompônio não seja técnica, pois como já visto, a idéia de nomen era cara ao direito, sendo um instrumento jurídico e não puramente lexical.

É preciso atentar que os dizeres de Sêneca são posteriores, já que Pompônio apenas confirma o afirmado por Masurio Sabino, no último séc. a.C., daí a superação da concepção de que a unificação era devida à possibilidade dos objetos serem passíveis de uma denominação coletiva, mas do fato de sua função e do direito o permitirem. ${ }^{76}$

Outros dois textos muito importantes são: D.50,16,119 e D.50,16,178,1.

Pomp. 3 ad Quint. Muc., D. 50,16,119. "Hereditatis" appellatio sine dubio continet etiam damnosam hereditatem: iuris enim nomen est sicuti bonorum possessio.

O termo herança, sem dúvida, contém, também, a herança danosa: pois é nome jurídico como a posse dos bens ${ }^{.77}$

\footnotetext{
72 Id. Ibid., p. 133 e 134.

Cfr. Lei das XII Tábuas, Tábua III.

Cfr. ORESTANO, Riccardo. op. cit., p. 135 e 136.

Id. Ibid., p. 136. Como comprova Gai. 4, 17.

Id. Ibid., p. 137.

7 Tradução livre.
} 
Ulp. 49 ad Sab., D. 50,16,178,1. "Hereditas" iuris nomen est, quod et accessionem et decessionem in se recipit: hereditas autem vel moxime fructibus angetur.

A herança é nome jurídico, o qual seja o acréscimo, seja o decréscimo, em si recebe: porém, é ampliada a herança, sobretudo, pelos frutos. ${ }^{78}$

Os dois fragmentos trazem a expressão nomen iuris que, se analisado só o primeiro texto, parece ser somente a denominação da herança, com um uso parecido com o nome moderno. Todavia, essa interpretação não seria possível devido à existência do segundo texto. ${ }^{79}$

Isso porque essa interpretação seria sem sentido para o segundo fragmento, demonstrando, pois, que a expressão nomen iuris não se refere ao significante, mas ao significado, sendo o próprio objeto que denomina, não se configurando como um conceito, mas como certa situação jurídica, que sob o nome de herança une os objetos, os elementos desta herança. ${ }^{80}$

Destes textos não se pode tentar retirar uma contraposição entre o nome, a herança e seus elementos. O que há aqui é uma situação de herança que não se contrapõe ao que a forma, sendo este o motivo pelo qual seus elementos podem mudar sem que ela mesma (a situação definida pelo nomen iuris) mude, veja-se que também aqui se pode considerar a herança como res, concepção material que justifica institutos como o da mancipatio familiae e da usucapio pro herede, que encaram os bens como res. ${ }^{81}$

\subsection{Segundo Período: a passagem da idéia de res ex distantibus para a de res incorporales}

Uma segunda série de textos irá tratar da distinção entre res corporales e res incorporales, ${ }^{82}$

78 Tradução livre.

79 Cfr. ORESTANO, Riccardo. op. cit., p.138-139.

${ }_{80}$ Id. Ibid., pp.139. Ver o fragmento Mod. 3 reg., D. 1,7,1,1, no qual o nome substitui o objeto.

81 Id. Ibid., p. 140-142.

82 Cfr. PUGLESE, Giovanni. op. cit., p. 233-262, desenvolve uma crítica, principalmente à obra de Michel Villey, que, baseando-se nestes fragmentos de Gaio, exclui a existência de situações subjetivas no Direito Romano. É interessante a passagem pela sua teoria, que, de forma indireta, tangencia a idéia defendida por Riccardo Orestano, de que não seria possível analisar as situações unificadas do ponto de vista subjetivo, sem, porém, negar a existência do direito subjetivo em Roma. Para o Autor, as Institutas de Gaio só reafirmam que não houve uma definição de direito subjetivo por parte do Direito Romano. O que ocorre é que em Gaio, assim como hoje, não se coloca o direito subjetivo como algo preponderante na doutrina jurídica, o que não significa que se desconheça a sua existência. Ademais, é preciso perceber que Gaio não foi o único jurista romano. Ulpiano, em D.1,3,41, faz, para o Autor, uma clara imputação subjetiva. Sendo assim, a tripartição personae, res, actiones não é presente em todos os juristas romanos e, em alguns deles, ao contrário do que ocorre com Gaio, a idéia de res não é preponderante. Por exemplo, em Sabino, as coisas eram estudadas por último. Apesar de não se guiar pelo direito subjetivo, não haveria aqui uma visão puramente objetiva. Além disso, o Autor ressalta que os Editos são o mais claro exemplo de imputação subjetiva na medida em que listam todas as ações, todos os direitos, todas as fórmulas admitidas pelo pretor em abstrato. Para a teoria de Michel Villey, os conceitos de pessoa, coisas e ações eram vistos sempre objetivamente, pois aquilo que hoje vemos como direitos seriam res para os romanos, que se subdividiriam em res corporales e res incorporales.

Esse pensamento se equivocaria ao admitir de forma literal o esquema de Gaio. Uma falha é percebida na própria 
definição, por parte de Michel Villey, de res corporales, que não seriam, por exemplo, somente um terreno, mas também a propriedade do terreno, sendo assim, o direito de propriedade (usar, fruir e dispor) seria uma coisa corpórea. E então Giovanni Pugliese se pergunta: se os direitos são coisas e as coisas são direitos, qual utilidade há na divisão entre coisas corpóreas e incorpóreas? Neste caso, o que há, segundo o Autor, é, mais uma vez a troca entre um bem e a propriedade deste bem. $\mathrm{O}$ que comprovaria que a concep̧̧̃o de res corporales não era formada por um objeto material e outro jurídico. Para isso bastaria observar que, mesmo se o termo dominium fosse de época avançada em Roma, antes, o seu correspondente, apesar de mais amplo (pois poderia ser encarado como uma propriedade ilimitada, assumindo tanto pessoas como coisas a posição de objeto), era o termo mancipium. Isso demonstra que os romanos não só conheciam as pessoas e as coisas, tratando a ambas objetivamente, mas que conheciam uma ligação jurídica imaterial entre elas, a mancipium, diferente tanto das pessoas como das res. Essa troca entre bem e propriedade do bem (que se faz presente até hoje) tem origem na concepção romana de que a propriedade era um poder absoluto sobre uma coisa, sendo assim, era natural que se pensasse que o bem fazia parte do patrimônio de uma pessoa e não que o que, na verdade, compunha seu patrimônio era a propriedade deste bem. Sendo assim, essa troca presente deste o início do Direito Romano, comprova que a noção de dominium ou de seu equivalente sempre existiu. A aquisição ou alienação nunca foram do bem em si, mas de sua propriedade. Quando se fala, pois, nas fontes em rem vindicare, adquirere, legare, se faz referência não ao bem em si, que seria composto de sua matéria e da propriedade, mas de adquirir e alienar o direito de propriedade. Desta forma, as res corporales eram unicamente objetos de atos ou relações jurídicas. O Autor cita como exemplo D. 30,71,5, no qual se ressalta a importância do ius sobre uma coisa deixada em legado. Admitir a concepção de Michel Villey seria o mesmo que dizer que o servus fructuarius seria uma espécie diversa de servo conforme seu adjetivo. Em D. 33,7,42,1; D. 3,6,58 e em D. 33,10,8 se faz alusão não a elementos intrínsecos ao bem, como quer Michel Villey, mas a elementos extrínsecos, conforme afirma Giovanni Pugliese. Nestes fragmentos a coisa é titular de direitos e obrigações (res como sujeito de direito era apenas uma metáfora). Na categoria de res incorporales, Michel Villey coloca os ius in re. Todavia, para o Autor, o tratamento de direitos como coisas não era real. Isso porque essa bipartição é de origem e influência sempre de Gaio, apesar da idéia de direito como algo incorpóreo apareça também em D. 5,10,116 e em escritos de Paulo que repete o esquema gaiano (D. 3,6,11; D. 8,1,14; D. 41,2,3; D. 41,3,4,26). Mas, apesar disso, nunca haveria uma igualação entre direito e coisa. Muitos fragmentos tratam da contraposição entre corpora e iura, mas isso, segundo o Autor, não significa que direitos e ações sejam coisas incorpóreas, mas que ao lado das coisas, também os direitos e ações fazem parte do patrimônio. Em D. $21,2,43$; D. 8,5,4; D. 50,16,222; D. 30,41; D. 18,6,7,2; D. 37,1,3; D. 44,2,7,5 se esclarece que não se coloca direitos e ações sob a categoria de res. Percebemos, assim, que o termo res incorporales é pouco frequente nas fontes e muitos juristas preferem não utilizá-lo, sendo quase que exclusivo de Gaio. O único modo de justificar a visão de direitos como res seria na hipótese de que um direito seja objeto de outro direito. O que faz cair por terra a concepção de que os iura eram coisas, não direitos subjetivos. O Autor afirna que, mesmo se admitimos que a obra de Gaio é a única a ser analisada, vemos que também para esse jurista havia a idéia de imputação subjetiva. Isso porque na categoria de res incorporales só são incluídos aqueles iura que são patrimoniais, isto é, os direitos referentes ao status da pessoa ou aqueles sobre família não eram submetidos à esfera das coisas incorpóreas. Logo, para o Autor, o fato de submeter alguns direitos a essa classificação ocorre puramente por eles fazerem parte do patrimônio e não devido à sua essência. A conclusão é de que essa denominação tem significado puramente terminológico para homogeneizar os elementos do patrimônio. Por isso, hoje damos mais relevância aos direitos considerando o patrimônio como uma universalidade de direitos. Poderíamos ter dado relevância aos bens, como aparece em um único fragmento de Ullpiano (D.50,16,49), sem fazer a troca entre bem e sua propriedade. Essa opção de Gaio foi muito útil, pois permitiu explicar fenômenos como os direitos sobre direitos, mas nunca suprimiu a natureza dos direitos, semelhante ao que hoje vemos como direito subjetivo, como imputação subjetiva. O próprio jurista nunca igualou direito e res, apenas usou um termo conveniente para lidar com a realidade. As visões objetiva e subjetiva não seriam, portanto, excludentes, mas complementares, a existência de uma não implicaria a inexistência da outra, como ocorre nos casos em que se admite direitos sobre direitos. $\mathrm{O}$ único direito patrimonial que Michel Villey não consegue encaixar nesta classificação é o dominium. Por isso, afirma que esse direito não é um ins, mas algo maior que se aplicava aos iura. A idéia de propriedade de servidões ou de qualquer outro direito ć, de acordo com Giovanni Pugliese, estranha ao Direito Romano e dogmaticamente errônea, já que o proprietário do direito é o titular do direito. Apesar de muito diversificada essas atribuições subjetivas, e isso é normal no esquema do Direito Romano, podemos afirmar que eles conheceram não o direito subjetivo, mas os direitos subjetivos. É preciso perceber também que ius. facultas e potestas são elementos diversos, mas com estrita relação. Lus representa a possibilidade de agir individualmente, é um direito protegido por uma ação. A facultas é uma possibilidade de agir mais genérica, por meio de uma permissão. Já a potestas representa um poder de comando, mas que não é um pressuposto para uma actio. Todos esses termos mostram que o sujeito de 
cujos principais fragmentos são do jurisconsulto Gaio: ${ }^{83}$

Gai. 2, 12. Quaedam praeterea res corporales sunt, quaedam incorporales.

Ademais, algumas coisas corpóreas são, algumas incorpóreas. ${ }^{84}$

Gai. 2, 13. Corporales hae sunt, quae tangi possunt, uelut fundus, homo, uestis, aurum, argentum et denique aliae res innumerabiles.

Corpóreas são aquelas, as quais podem ser tocadas, como a propriedade, o homem, o vestido, o ouro, a prata e, em suma, inumeráveis outras coisas. ${ }^{85}$

Gai. 2, 14. Incorporales sunt, quae tangi non possunt, qualia sunt ea, quae in iure consistunt, sicut hereditas, ususfructus, obligationes quoquo modo contractae. nec ad rem pertinet, quod in hereditate res corporales continentur, et fructus, qui ex fundo percipiuntur, corporales sunt, et id, quod ex aliqua obligatione nobis debetur, plerumque corporale est, ueluti fundus, homo, pecunia: nam ipsum ius successionis et ipsum ius utendi fruendi et ipsum ius obligationis incorporale est. eodem numero sunt iura praediorum urbanorum et rusticorum.

Incorpóreas são as que não podem ser tocadas, tais como são aquelas que consistem em direitos, como a herança, o usufruto, as obrigações por qualquer modo contraídas. Nem interessa que na herança estejam contidas coisas corpóreas, como frutos, os quais da propriedade sejam percebidos, que são corpóreos, e aquilo, que de outra obrigação seja devido a nós, e que em maior parte é corpóreo, como a propriedade,

direitos podia em vários sentidos, expressar a sua vontade. O direito de fazer alguém se comportar de certa forma não existe. O que existe é a pretensão de que alguém realize aquele comportamento, que se não realizado, irá originar uma ação. O que os romanos fizeram foi simplesmente ir direto para a ação, dando-a aos sujeitos.

Tradução livre.

85 Tradução livre. 
o homem, o dinheiro: efetivamente, o próprio direito de sucessão e o próprio direito de usar e fruir e o próprio direito de obrigações são incorpóreos. Da mesma categoria são os direitos dos prédios urbanos e rústicos [servidões]. ${ }^{86}$

Porém, essa noção aparece primeiramente com Cícero, que utiliza as expressões res quae sunt - que possuem uma existência material, como a supellex - e res quae intelleguntur - que existem somente intelectualmente, como as gens, o que quebra o gênero corpora ex distantibus. ${ }^{87}$

Isso demonstra uma dificuldade em conciliar essas duas classificações, o que indica uma sobreposição de uma em relação à outra, paralelamente com a mudança da regulação jurídica de alguns desses complexos unificados. ${ }^{88}$

Com Gaio, séc. II d.C., a herança perde seu caráter material, já que este jurista a classifica como coisa incorpórea, mudança esta por ele reconhecida, como se depreende de Gai. 2,53-55. ${ }^{89}$

Trata-se de um verdadeiro processo de desmaterialização que atinge não só a herança, mas também as servidões, pois, de acordo com D. $8,1,14,{ }^{90}$ foi proibido seu usucapião, já que se enquadrariam na categoria de res incorporales, proibição que não foi reconhecida para as servidões rústicas, anomalia percebida por Gai. 2, 28-29.91 A idéia de que só as coisas corpóreas poderiam ser objeto de posse está em D. 41,2,3.92

Disso conclui - se que a classificação res corporales e res incorporales supera a concepção do primeiro bloco de textos analisados, que adotavam a idéia das res ex distantibus. ${ }^{93}$

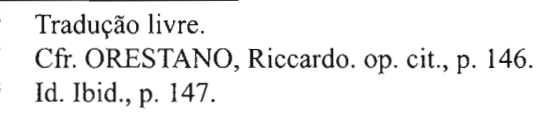

89 Gai. 2, 53. Et in tantum haec usucapio concessa est, ut et res, quae solo continentur,anno usucapiantur. 54 Quare autem hoc casu etiam soli rerum annua constituta sit usucapio, illa ratio est, quod olim rerum hereditariarum possessione ipsae hereditates usucapi credebantur, scilicet anno: Lex enim XII tabularum soli quidem res biennio usucapi iussit, ceteras uero anno: ergo hereditas in ceteris rebus uidebatur esse, quia soli non est [quia neque corporalis est]; et quamuis postea creditum sit ipsas hereditates usucapi non posse, tamen in omnibus rebus hereditariis, etiam quae solo tenentur, annua usucapio remansit. 55. Quare autem omnino tam inproba possessio et usucapio concessa sit, illa ratio est, quod uoluerunt ueteres maturius hereditates adiri, ut essent, qui sacra facerent, quorum illis temporibus summa obseruatio fuit, ut et creditores haberent, a quo suum consequerentur.

90 Paul. 15 ad Sab., D. 8,1,14. Servitutes praediorum rusticorum etiamsi corporibus accedunt, incorporales tamen sunt et ideo usu non capiuntur: vel ideo, quia tales sunt servitutes, ut non habeant certam continuamque possessionem: nemo enim tam perpetuo, tam continenter ire potest, ut nullo momento possessio eius interpellari videatur. Idem et in servitutibus praediorum urbanorum observatur.

91 Gai. 2, 28. Res incorporales traditionem non recipere manifestum est. 29. Sed iura praediorum urbanorum in iure cedi tantum possunt; rusticorum uero etiam mancipari possunt.

92 O texto apresentado pelo Autor é o seguinte: Paul. 54 ad ed., D. 42,2,3. Possideri autem possunt, quae sunt corporalia. No entanto, esse texto não confere com o apresentado por Theodor Mommsen em D. 42,2,3, a indicação correta é , pois, D. 41,2,3.

93 Cfr. ORESTANO, Riccardo. op. cit., p. 148 e 149. 
É de se ter em mente que a concepção de nomen iuris nunca fọi abstrata, sempre carregou certo nível de materialidade, pois ela apenas justificava a sua existência como entidade material encarada como corpus ou res. ${ }^{94}$

A partir da tomada de consciência de que nem todas as res eram iguais, pois algumas poderiam ser de início, tocadas e outras não, apesar de todas elas serem abarcadas pela denominação res, há um passo inevitável à desmaterialização. ${ }^{95}$

O texto de Cícero, por ser leigo, utiliza de um termo subjetivo para definir as res incorporales, a saber, o termo intellegere, que é substituído por Gaio, pela palavra ius, um termo mais objetivo. ${ }^{96}$

Daí advém a interpretação comum de que as coisas incorpóreas são as relações jurídicas e os direitos. Todavia, na opinião do Autor, isso revela a interpretação dos juristas pós-clássicos e não a de Gaio, ocorrendo nos dois fragmentos a tratarem do assunto $o$ acréscimo da preposição in anteriormente à iure, fruto, talvez, de interpolações. ${ }^{97}$

O Autor defende que a construção consistere mais ablativo resulta no significado de haver fundamento no e não de consistir em, pois para se atingir este último significado seria necessário utilizar - se da expressão in iuribus consistunt e não in iure consistunt. Essa questão é muito relevante, pois se passa de uma concepção subjetiva para uma objetiva. ${ }^{98}$

Desta forma, as res incorporales de Gaio se assemelhariam ao iure cohaerent de Sêneca, pois não seriam fruto de mero ato intelectivo, mas uma situação determinada pelo direito, pois é ele que admite a existência deste tipo de res, resultando desse fato a sua concepção objetiva.

Não se deixa, com essa nova classificação, de admitir essa res como algo de existência real, mas a diferença é que, ao contrário do que ocorria com a classificação

ORESTANO, Riccardo. op. cit., p. 149.

Id. Ibid., p. 150.

Id. Ibid., p. 151.

97 Il Problema delle Persone Giuridiche in Diritto Romano, cit. (nota 9.Intr. supra), p. 151. Os fragmentos são Gai. 2 inst., D. 1,8,1,1. Quaedam praeterea res corporales sunt, quaedam incorporales. Corporales hae sunt, quae tangi possunt, veluti fundus homo vestis aurum argentum et denique aliae res innumerabiles: incorporales sunt, quae tangi non possunt, qualia sunt ea, quae in iure consistunt, sicut hereditas, usus fructus, obligationes quoquo modo contractae. Nec ad rem pertinet, quod in hereditate res corporales continentur: nam et fructus, qui ex fundo percipiuntur, corporales sunt, et id quod ex aliqua obligatione nobis debetur plerumque corporale est, veluti fundus homo pecunia: nam ipsum ius successionis et ipsum ius utendi fruendi et ipsum ius obligationis incorporale est. Eodem numero sunt et iura praediorum urbanorum et rusticorum, quae etiam servitutes vocantur. I. 2,2,2. Incorporales autem sunt quae tangi non possunt. qualia sunt ea quae in iure consistunt: sicut hereditas, usus fructus, obligationes quoquo modo contractae. nec ad rem pertinet quod in hereditate res corporales continentur: nam et fructus qui ex fundo percipiuntur corporales sunt, et id quod ex aliqua obligatione nobis debetur plerumque corporale est, veluti fundus, homo, pecunia: nam ipsum ius hereditatis et ipsum ius utendifruendi et ipsum ius obligationis incorporale est.

Cfr. ORESTANO, Riccardo. op. cit., p. 152. 
anterior, as res incorporales não poderiam mais se identificar com seus elementos de forma direta, agora há certa contraposição aos seus elementos, pois ela existe em razão e dentro do direito, daí o termo iure. ${ }^{99}$

Outro fragmento que comprova não serem as res incorporales fruto de um ato intelectivo, subjetivo é o D. 5,3,50, ${ }^{100}$ de Papiniano, que justifica a possibilidade da herança existir mesmo sem um corpus.

$\mathrm{Na}$ classificação anterior, a herança, por exemplo, era considerada como sendo ela mesma os seus elementos, não se distinguindo os seus elementos materiais e outros que a eles estivessem relacionados. Agora, compreende-se que a herança é algo diferente de seus elementos, podendo se composta tanto de elementos materiais como imateriais, analisando - se a sua relação com os seus elementos, que não são mais vistos unitariamente. A partir deste momento se vê a herança como sendo composta de corpora et iura ou corpora et actiones. ${ }^{101}$

Percebemos, assim, que o primeiro bloco de textos foi concebido no período do final da República até o início do Principado (de César a Augusto) e o segundo bloco é referente ao período da segunda metade do séc.II d.C até o início do séc. III (idade dos Antoninos e dos Severos). ${ }^{102}$

Assim, há uma desmaterialização das res ex distantibus e a tendência de considerá-las como res incorporales, atingindo, indistintamente, as gens, a herança e, pouco depois, o grex, a mais típica, segundo o Autor, representante das res ex distantibus.

Um grande problema interpretativo referente à primeira classificação no que toca ao grex é que um texto de Pompônio impede que haja a usucapião do rebanho de forma unitária, exigindo a usucapião de cada ovelha, o que é totalmente contraditório com a noção de res ex distantibus. ${ }^{103}$

Pomp. 30 ad Sab. D. 41,3,30,2. De tertio genere corporum videndum est. Non autem grex universus sic capitur usu quomodo singulae res, nec sic quomodo cohaerentes. Quid ergo est? Etsi ea natura eius est, ut adiectionibus corporum maneat, non item tamen universi gregis ulla est usucapio, sed singulorum animalium sicuti possessio, ita et usucapio. $\mathrm{Nec}$ si quid emptum immixtum fuerit gregi augendi eius gratia, idcirco possessionis causa mutabitur, ut, si reliquus grex dominii mei sit, haec quoque ovis, sed singulae suam

\footnotetext{
99 ORESTANO, Riccardo. op. cit., p. 152.

100 Pap. 6 quaest., D. 5,3,50. Hereditas etiam sine ullo corpore iuris intellectum habet.

101 Cfr. ORESTANO, Riccardo. op. cit., p. 153 e 154. Como demonstra o seguinte fragmento: Ulp 75 ad ed., D. $44,2,7,4$. Idem erit probandum et si quis debitum petierit a debitore hereditario, deinde hereditatem petat, vel contra si ante hereditatem petierit et postea debitum petat: nam et hic obstabit exceptio: nam cum hereditatem peto, et corpora et actiones omnes, quae in hereditate sunt, videntur in petitionem deduci.

102 Id. Ibid., p. 156 e 157.

103 Id. Ibid., p.158 - 160.
} 
causam habebunt, ita ut, si quae furtivae erunt, sint quidem ex grege, non tamen usucapiantur.

Deve ser observado acerca do terceiro gênero das coisas que, porém, não é usucapido o conjunto do rebanho como da maneira que as coisas individuais, nem do modo [das coisas] ligadas. O que há, portanto? Ainda que a natureza dela seja mantida com a adição de corpos, não existe, porém, usucapião, igualmente, da união do rebanho, mas como [ocorre com a] posse dos animais individuais, deste modo há usucapião. Nem por esta razão, se forem comprados [animais] para aumentar o rebanho, será mudada a causa da posse, de sorte que, se o restante do rebanho de minha propriedade for, também o será esta ovelha, mas individualmente será tida por sua [própria] causa, tal como, se algumas forem furtadas, sendo certamente do rebanho, não, porém, serão usucapidas. ${ }^{104}$

Apesar de não negar que o texto contenha interpolações, o Autor esclarece que, na verdade, não há necessariamente uma contradição no texto apresentado. $\mathrm{O}$ que ocorre é que na primeira parte do texto, há o comentário aos três gêneros, proveniente de Sabino, e na última parte há uma influência da divisão entre res corporales e incorporales. ${ }^{105}$

Contradições em relação ao grex e à herança permanecem nas fontes, como espelho de diferentes fases e modos de considerar essas situações unificadas. ${ }^{106}$

Todo esse processo de desmaterialização faz com que o Direito Romano passe a encarar as situações unificadas não como conceitos concretos, mas abstratos. ${ }^{107}$

\subsection{Terceiro Período: a concepção de Universitas}

O passo seguinte nesta evolução aparece com a idéia de universitas, que deriva do adjetivo universus, usado muitas vezes em época republicana. ${ }^{108}$

Uma das formas pelas quais esse termo era empregado é por meio de sua associação com um determinativo, assumindo o significado de "conjunto de" como em universitas agrorum, fundi, aedificii, bonorum etc. Já o adjetivo universus aparece com o significado de tudo ou inteiro como universa res e universa alimenta.

\footnotetext{
Tradução livre.

Cfr. ORESTANO, Riccardo. op. cit., p.160 e 161.

106 Id. Ibid., p. 162.

107 Id. Ibid., p. 162 e 163.

108 Id. Ibid., p.163.
} 
Todavia, em certas situações, o termo universitas aparece denominando um conjunto, mas sendo tratado como algo diverso de seus integrantes, passando a situação unificada a ser diversa de seus elementos, podendo se contrapor a esses elementos. ${ }^{109}$

Para o Autor, considerar que esse último uso é somente encontrado em época pós-clássica, sendo fruto de interpolações, tal como afirmar que ele foi utilizado para todas as situações unificadas do Principado, é tomar uma atitude anti-histórica.

A importância, neste tema, estaria não em revelar quando apareceu 0 conceito abstrato de universitas, mas saber se ele foi aplicado genericamente a todas as situações unificadas ou se acaso houve contradições em sua aplicação, hesitações, sendo que R. Orestano opta pela segunda alternativa.

O Autor dá como exemplo duas fontes: a primeira é um texto das institutas de Gaio, que se refere a uma coletividade de pessoas, texto que é considerado autêntico.

Gai. 2, 11. Quae publicae sunt, nullius uidentur in bonis esse; ipsius enim uniuersitatis esse creduntur. Priuatae sunt, quae singulorum hominum sunt.

As coisas que são públicas são consideradas como não estando dentre os bens de ninguém; de fato, elas próprias são tidas como sendo da universalidade. Privadas são aquelas que são dos homens individuais. ${ }^{110}$

Para E. Albertário, nesse texto, como em todos os textos clássicos há uma classificação entre coisas que são omnium, universitates, nullius e singulorum. Todavia, universitas, neste contexto, significaria, simplesmente, os membros da civitas e, não uma entidade com personalidade jurídica. ${ }^{111}$

Haveria, portanto, sempre uma menção, nos textos clássicos, à concretude da universitas e quando isso não fosse feito, subentender-se-ia que se faz referência à universitas civium. ${ }^{112}$

O segundo é um texto de Ulpiano que se refere ao grex, um típico corpus ex distantibus.

\section{Ulp. 17 ad Sab., D. 7,1,70,3. Sed quod dicitur debere eum summittere, totiens verum est, quotiens gregis vel armenti vel equitii, id est universitatis usus fructus legatus est: ceterum si singulorum capitum, nihil supplebit.}

\footnotetext{
Id. Ibid., p.164.

Tradução livre.

111 ALBERTÁRIO, Emilio. Corpus e Universitas nella Designazione della Persona Giuridica. Studi di Diritto Romano. Milano: Giuffrè, 1933. v. 1. p. 112 e 113.

112 Id. Ibid., p.113.
} 
Mas o que é dito que se deve substituir, frequentemente é verdade, todas as vezes que o rebanho ou de gado ou de eqüinos, isto é, da universalidade foi legado o usufruto: certamente se das cabeças individuais, nada reparará. ${ }^{113}$

Considera-se que esse texto tenha sido modificado por Ulpiano, não pelos compiladores pós-clássicos. Isso porque esse é o único texto em que aparece esse tipo de qualificação para a grex, demonstrando que a concepção de Ulpiano já havia superado a idéia de divisão entre os corpora, na qual se inclui o corpus ex distantibus, evidenciando essa evolução ruma à desmaterialização. ${ }^{114}$

O mesmo ocorre com a qualificação do peculium castrense, somente uma única vez tido como universitas. ${ }^{115}$

Analisemos agora os textos de Gaio.

Gai. 2, 97. Hactenus tantisper admonuisse sufficit, quemadmodum singulae res nobis adquirantur: nam legatorum ius, quo et ipso singulas res adquirimus, opportunius alio loco referemus. uideamus itaque nunc, quibus modis per uniuersitatem res nobis adquirantur.

Até aqui, durante este tempo, sugere-se apresentar, de que maneira por nós são adquiridas as coisas singulares: de fato, quanto ao próprio direito de legado, pelo qual também adquirimos as coisas singulares, oportunamente em outro lugar referiremos. Consideremos, portanto, agora, aqueles modos pelos quais por nós são adquiridas as coisas universalmente. ${ }^{116}$

Gai. 2, 191. Post haec uideamus de legatis. quae pars iuris extra propositam quidem materiam uidetur: nam loquimur de his iuris figuris, quibus per uniuersitatem res nobis adquiruntur: sed cum omni modo de testamentis de que heredibus, qui testamento instituuntur, locuti simus, non sine causa sequenti loco poterit haec iuris materia tractari.

Após isto, veremos acerca dos legados. Esta parte do direito, de fato, fora do propósito da matéria é considerada: pois falamos sobre estas figuras jurídicas, pelas quais de modo universal são adquiridas as coisas por nós: mas, como sobre todos os aspectos acerca dos testamentos e dos herdeiros, que foram, pelo testamento, instituídos, discorremos, não

\footnotetext{
113 Tradução livre.

114 Cfr. ORESTANO, Riccardo. op. cit., p.166 e 167.

115 Ver Ulp. 15 ad ed. D. 5,3,20,10. Non solum autem in hereditate utimur senatus consulto, sed et in peculio castrensi vel alia universitate.

116 Tradução livre.
} 
sem motivo, no lugar seguinte, poderá ser tratada esta matéria de direito. ${ }^{117}$

Esses textos tratam da questão do adquirere per universitatem. Apesar de muitos autores se basearem neste texto para afirmar que a concepção de universitas não é de origem tardia, para o Autor, Gaio, neste texto, não utiliza uma concepção abstrata de universitas, pois o jurista, contrapondo a aquisição singulae res e a per universitatem, se refere à aquisição dos bens em bloco, não à uma concepção abstrata, o que se confirma em (Epistola Gai, 2,2) que trata da aquisição de omnia bona simul. ${ }^{118}$

O evoluir desta concepção se dá nos séculos IV e V, quando os Fragmenta Augustodunensia transforma o fideicommissum hereditatis de Gaio em fideicommissum universitatis, desmaterializando completamente a figura da hereditas antes da época pósclássica. ${ }^{119}$

Isso não exclui a idéia de que os juristas pós clássicos tenham contribuído para o desenvolvimento do conceito abstrato de universitas, ${ }^{120}$ todavia, é inegavelmente clássica a premissa para esse desenvolvimento, isto é, a concepção dos corpora ex distantibus dentro da categoria de res incorporales. ${ }^{121}$

O termo corpus, desde época antiga, foi operado com o sentido de um conjunto unitariamente considerado, fazendo - se analogia ao corpo humano, como já foi visto. É no Principado que esse termo passa a ser usado nas fontes jurídicas para designar conjuntos de base pessoal (associativo), indicando certo tipo de grupo de pessoas. ${ }^{122}$

Por isso, esse termo aparece, muitas vezes, ligado com o tipo de pessoa a que se refere como corpus fabrorum, corpus naviculariorum, entre outros, já que se entende o termo corpus como a mesma coisa que seus elementos, tal como se dá com os corpora ex distantibus.

É preciso observar que esse termo podia ter várias significações, indicando seja a entidade física do homem, seja o conjunto de pessoas ou coisas, usado, nesta segunda acepção, de forma metafórica, dotado de conteúdo material e ao mesmo tempo referente a uma unidade orgânica. ${ }^{123}$

\footnotetext{
117 Tradução livre.

118 Cfr. ORESTANO, Riccardo. op. cit., p.167 e 168

119 Id. Ibid., p..169 e 170.

120 Disto resulta a crítica de CATALANO, Pierangelo. op. cit., p.44 e 45 à concepcão segundo a qual o uso dos termos corpus e universitas demonstrariam que o direito clássico teria uma noção concreta, coletiva e os pós clássicos uma concepção abstrata, de unidade da pessoa jurídica. Ademais, para o Autor, é necessário ressaltar que essa abstração nunca teria sido completa, sendo barrada pelos juristas e imperadores. Isso porque a referência ao ius omnium seria permanente, seja no que concerne ao populus, seja no que concerne aos municipia e collegia.

(2) Cfr. ORESTANO, Riccardo. op. cit., p. 170.

122 Id. Ibid., p.172 e 173

123 Id. Ibid., p. 173.
} 
Passando a significar tecnicamente situações de base pessoal, o uso metafórico do termo corpus abre caminho para a qualificação medieval e na idade moderna, também metafórica, de atribuir a essas situações a qualificação de pessoa. ${ }^{124}$

Daí a dificuldade de saber quando o termo corpus adquire conteúdo material ou antropomórfico quando aparece nas fontes referindo - se a civitates ou collegia. Mas, mesmo assim, nunca deixou de se identificar com aquilo que designava, não podendo ser contraposto aos seus elementos.

A partir do século III d. C. há uma lenta desmaterialização do uso de corpus já visto como algo de distinto ${ }^{125}$ do que seus elementos tomados singularmente, o que não significa a sua abstração, que só ocorre quando o conjunto, o todo é tido como nitidamente diverso daquilo que o compõe. ${ }^{126}$

Interessante, para isso, é observar o texto de Ulpiano sobre os escravos públicos, que utiliza o termo corpus com uma conotação abstrata, de acordo com um pensamento já presente em sua época. ${ }^{127}$

Ulp. 8 de of. Proconsul., D. 48,18,1,7. Servum municipum posse in caput civium torqueri saepissime rescriptum est, quia non sit illorum servus, sed rei publicae. Idemque in ceteris servis corporum dicendum est: nec enim plurium servus videtur, sed corporis.

Foi posto por escrito, muitas vezes, que pode o servo dos munícipes demandar contra os cidadãos, pois o servo não é deles, mas da coisa pública. E igualmente deve ser dito quanto a todos os demais servos do corpo: de fato, não como de vários, mas como do corpo é visto o servo. ${ }^{128}$

E é neste ponto que se passa a identificar esse termo com a palavra universitas, evoluindo os corpora hominum, da mesma forma que o grex, a hereditas e o peculium castrense, sendo todos, posteriormente, denominados de universitas, como sinônimo de corpus, algo que ocorre no fim do século III d.C. ${ }^{129}$

É a partir deste material, de época clássica, que, por vezes, chegava a trabalhar com analogia, que os compiladores justinianeus, passam a tentar sistematizar e dar uma regulamentação única às situações unificadas.

Todavia, a doutrina não é unânime quanto ao período e à originalidade dos textos apontados por R. Orestano.

\footnotetext{
124 Id. Ibid., p.174.

125 O Autor exemplifica com os seguintes fragmentos: Ulp. 24 ad ed., D. 10,4,7,3; Maec. 15 fidec., D.40,5,36,2; Marc. 2 iudic. public., D. 47,22,3,1 e D. 47,22,3,2; Ulp. 46 ad ed., D. 50,16,195,2.

126 Cfr. ORESTANO, Riccardo. op. cit., p.174 e 175.

127 Id. Ibid., p.175.

128 Tradução livre.

129 Cfr. ORESTANO, Riccardo. op. cit., p.176.
} 
Para E. Albertário, a mudança desta concepção (o termo corpus passar a indicar um ente unitário diverso da pluralidade de seus membros) começa a ocorrer em idade tardia, não em época clássica. ${ }^{130}$

Essa evolução seria influência de conceitos teológicos no Direito Romano, surgindo textos interpolados, para afirmarem a alteração deste conceito.

Sendo assim, o texto acima apresentado (D. 48,18,1,7) seria fruto de interpolações.

As passagens interpoladas seriam, segundo o Autor, illorum e idemque in ceteris servis corporum dicendum est: nec enim plurium servus videtur, sed corporis. Isso porque seria contraditório dizer que o servus municipium não seria servus illorum e o plurium na frase seguinte, deveria indicar não a maior parte, mas todos os componentes do corpus. ${ }^{131}$

Essas interpolações seriam fruto da vontade de se esclarecer o novo conceito de corpus, mas acabaram, para isso, resultando em textos repletos de banalidades e incongruências. O texto original do fragmento acima deveria ser o seguinte: Servum municipium posse in caput civium torqueri saepissime rescriptum est, quia non sit (singulorum) servus sed rei publicae. Desta forma, evidente estaria a contraposição entre as res singulorum e as res universitatis. ${ }^{132}$

Também interpolado seria, para E. Albertário, o texto D. 12,2,34,1, pois haveria uma incongruência ao contrapor municipium e corpus, sendo a expressão defensor municipium de origem clássica e a expressão vel cuisvis corporis de origem pós clássica. ${ }^{133}$

Ulp. 26 ad ed., D. 12,2,34,1. Defensor municipum vel cuiusvis corporis iusiurandum deferre potest, si super hoc mandatum habeat.

O defensor dos munícipes ou de qualquer [outro] corpo [universalidade] pode deferir o juramento, se sobre isto tenha um mandado [se lhe foi dado este poder por mandado] 134

O mesmo se daria com D. 37,1,3,4, que refletiria a evolução rumo à abstração do conceito de corpus. Neste trecho, os termos interpolados seriam et societatibus et decuriis et corporibus. ${ }^{135}$

Ulp. 39 ad ed., D. 37,1,3,4. A municipibus et societatibus et decuriis et corporibus bonorum possessio adgnosci potest.

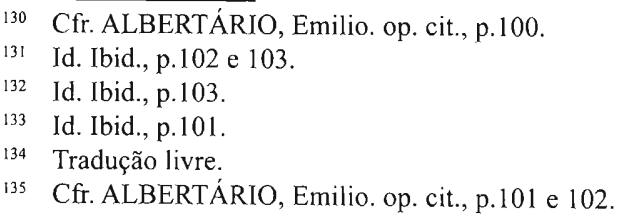


Proinde sive actor eorum nomine admittat sive quis alius, recte competet bonorum possessio: sed et si nemo petat vel adgnoverit bonorum possessionem nomine municipii, habebit municipium bonorum possessionem praetoris edicto.

Pelos munícipes e pelos sócios e pelas decúrias e corporações pode ser admitida a posse dos bens. Por isso, quer pelo actor se admita em nome deles, quer por qualquer outro, a quem legitimamente caiba a posse dos bens: mas também se ninguém requerer ou admita a posse dos bens em nome do município, haverá o município a posse dos bens pelo edito do pretor. ${ }^{136}$

Outro texto interpolado seria o de Gaio (D. 3,4,1,1). Isso porque, na concepção clássica, collegium e corpus seriam sinônimos, ambos se referindo ao conjunto de pessoas, não sendo possível, pois, que o jurista tenha escrito quibus permissum est corpus habere collegii, diferenciando corpus collegii de seus membros, algo só pensável no período pós clássico. ${ }^{137}$

Gai. 3 ad provinc., D. 3,4,1,1. Quibus autem permissum est corpus habere collegii societatis sive cuiusque alterius eorum nomine, proprium est ad exemplum rei publicae habere res communes, arcam communem et actorem sive syndicum, per quem tamquam in re publica, quod communiter agi fierique oporteat, agatur fiat.

Àqueles, porém, a quem é permitido ter corpo de colégio, de sociedade ou outro com o mesmo nome, próprio é, ao exemplo das coisas públicas [ente público], ter bens comuns, arca comum e administrador ou síndico, por quem, como na coisa pública [ente público], se execute ou se faça o que geralmente deve ser executado ou feito. ${ }^{138}$

O Autor conclui que o termo corpus, em época justinianéia, é de origem espúria, sendo adicionado após o termo collegium para enfatizar a existência de um sujeito de direito diverso da pluralidade de membros. Com a mesma situação nos depararíamos ao observar o emprego do termo universitas, como uma coletividade diversa de seus integrantes. ${ }^{139}$

E. Albertário começa pelo fragmento D. $2,4,10,4 .{ }^{140}$ O termo vel universitatem seria espúrio e, portanto, interpolado.

\footnotetext{
136 Tradução livre.

137 Cfr. ALBERTÁRIO, Emilio. op. cit., p.103 e 104.

138 Tradução livre.

139 Cfr. ALBERTÁRIO, Emilio. op. cit., p.104.

140 Ulp. 5 ad ed., D. 2,4,10,4. Qui manumittitur a corpore aliquo vel collegio vel civitate, singulos in ius
} 
Em D. 46,8,9141 seria curiosa a denominação do actor de uma corporação, de magister. Isso porque o magister havia sido abolido no direito justinianeu, mas, ao invés de retirá-lo do texto, os interpoladores alteraram o seu significado, o admitindo como representante do colégio. ${ }^{142}$

No texto acima referido (D. 3,4,1,1) e nos fragmentos seguintes (D. 3,4,1,2 e D. 3,4,1,3), é inconcebível, para o Autor, que se passe improvisadamente de uma concepção concreta quibus autem permissum est/quod si nemo eos defendat, trecho que se refere aos membros da corporação, para a noção de universitas. $^{143}$

Gai. 3 ad ed provinc., D. 3,4,1,2. Quod si nemo eos defendat, quod eorum commune erit possideri et, si admoniti non excitentur ad sui defensionem, venire se iussurum proconsul ait. Et quidem non esse actorem vel syndicum tunc quoque intellegimus, cum is absit aut valetudine impedietur aut inhabilis sit ad agendum.

Quanto ao fato de que ninguém os [os sócios] defenda, o Proconsul afirmou que ordenará que possuam o que deles é comum, já que advertidos, não provocaram a sua defesa, e que se venda. E, certamente, entendemos que não possuem administrador ou síndico, quando este estiver ausente ou porque a saúde o impede ou porque seja incapaz de agir. ${ }^{144}$

Gai. 3 ad ed. provinc., D. 3,4,1,3. Et si extraneus defendere velit universitatem, permittit proconsul, sicut in privatorum defensionibus observatur, quia eo modo melior condicio universitatis fit.

E se um estranho quiser defender a universalidade, [isto] é permitido pelo Proconsul, do mesmo modo como é observado nas defesas dos indivíduos, pois deste modo fazse melhor a situação da universalidade. ${ }^{145}$

É no período pós clássico que o termo universitas assume o significado de ente distinto de seus integrantes. ${ }^{146}$

vocabit: nam non est illorum libertus. Sed rei publicae honorem habere debet et si adversus rem publicam vel universitatem velit experiri, veniam edicti petere debet, quamvis actorem eorum constitutum in ius sit vocaturus.

141 Ulp. 9 ad ed., D. 46,8,9. Actor a tutore datus omnimodo cavet: actor civitatis nec ipse cavet, nec magister universitatis, nec curator bonis consensu creditorum datus.

142 Cfr. ALBERTÁRIO, Emilio. op. cit., p.105 e 106.

143 Id. Ibid., p.106 e 107.

144 Tradução livre.

145 Tradução livre.

146 Como comprovariam, segundo Emilio Albertário, os textos: Zeno, C. 1,23,7,2 (de 477) e Iust., C. 2,58,2,5 (de 531). 
Assim, percebe-se que tanto o termo universitas como o termo corpus, no direito clássico sempre se referiam à coletividade, nunca a uma unidade. ${ }^{147}$

Na visão do Autor, há uma preferência, nos textos romanos, de se referir aos municipes e não ao municipium e quando se utiliza do último termo, isto é feito para se referir à coletividade de membros, sendo o servus communis, a res communis de omnium civium. $^{148}$

A idéia de que os municípios são corpus incertum evidencia o fato de que não se entendia o município como pessoa jurídica. ${ }^{149}$

Para melhor demonstrar sua concepção, o Autor ${ }^{150}$ apresenta mais três textos, dois, para ele, genuínos (D. $41,1,41$ e D. 43,24,11,1) e um interpolado no termo municipii (D. 44,1,23).

Ulp. 9 ad ed., D. 41,1,41. Statuas in civitate positas civium non esse, idque Trebatius et Pegasus: dare tamen operam praetorem oportere, ut, quod ea mente in publico positum est, ne liceret privato auferre nec ei qui posuerit. Tuendi ergo cives erunt et adversus petentem exceptione et actione adversus possidentem iuvandi.

As estátuas postas na cidade não são dos cidadãos, e isto [dizem] Trebácio e Pégaso: porém, é necessário dar atenção o pretor, àquilo que por esta intenção foi colocado em público, que não seja lícito o particular obter nem aquele que a colocou. Logo, serão defendidos os cidadãos seja com a exceção contra o que reclamar seja com ação em auxílio contra o possuidor. ${ }^{151}$

Ulp. 71 ad ed., D. 43,24,11,1. Quaesitum est, si statuam in municipio ex loco publico quis sustulerit vel vi vel clam, an hoc interdicto teneatur. Et exstat cassii sententia eum, cuius statua in loco publico in municipio posita sit, quod vi aut clam agere posse, quia interfuerit eius eam non tolli: municipes autem etiam furti acturos, quia res eorum sit quasi publicata: si tamen deciderit, ipsi eam detrahunt: et haec sententia vera est.

Foi perguntado, se aquele que retirou seja por violência, seja clandestinamente, uma estátua do local público no município, seria abarcado por este interdito. E existe a opinião de Cássio o qual [disse] que aquele cuja estátua estava posta em local público do município e [foi retirada]

\footnotetext{
147 Cfr. ALBERTÁRIO, Emilio. op. cit., p.113.

148 Id. Ibid., p.114.

149 Id. Ibid., p.114.

iso Id. Ibid., p.119.

151 Tradução livre.
} 
por violência ou clandestinamente pode agir, porque é do interesse dele que ela não fosse retirada: os munícipes, porém, poderão agir também pela [ação] de furto, pois as coisas deles são como as públicas: se, no entanto, caiu, eles próprios a tirarão, e esta opinião é a correta. ${ }^{152}$

Lab. 6 pith. a Paulo epit., D. 44,1,23. Paulus: si quis statuam in municipio ea mente posuit, ut ea municipii esset, et eam petere vult, excludi eum oportet praescriptione in factum data.

Paulo: se alguém pôs uma estátua no município com a intenção que ela fosse do município e quer reclamá-la, é necessário que ele seja excluído pela prescrição dada ao fato. ${ }^{153}$

No direito justinianeu, não seria de caráter excepcional a capacidade jurídica dos municipia e das civitates. O texto de Paulo (D. 41,2,1,22) representaria o pensamento clássico, já o sucessivo texto de Ulpiano (D. 41,2,2) indicaria a visão pós clássica. ${ }^{154}$

Paul. 54 aded., D. 41,2,1,22. Municipes per se nihil possidere possunt, quia universi consentire non possunt. Forum autem et basilicam hisque similia non possident, sed promiscue his utuntur. Sed Nerva filius ait, per servum quae peculiariter adquisierint et possidere et usucapere posse: sed quidam contra putant, quoniam ipsos servos non possideant.

Os munícipes nada podem possuir por si mesmos, pois não podem todos juntos consentir. Além disso, o foro e a basílica e [as coisas] similares, não são possuídas, mas indistintamente, por eles são utilizadas. Mas Nerva, o filho, afirma que, por meio de um servo, pode se possuir e usucapir [aquilo] que se adquiriu a título de pecúlio. No entanto, alguns consideram o contrário, pois os servos, eles mesmos, não possuem. ${ }^{155}$

Ulp. 70 ad ed., D. 41,2,2. Sed hoc iure utimur, ut et possidere et usucapere municipes possint idque eis per servum et per liberam personam adquiratur.

Mas por razão de direito entendemos que os munícipes possam não só possuir, como também usucapir aquilo que, para eles, tenha sido adquirido, seja por servo seja por pessoa livre. ${ }^{156}$

152 Tradução livre.

153 Tradução livre.

154 Cfr. ALBERTÁRIO, Emilio. op. cit., p. 120.

155 Tradução livre.

156 Tradução livre. 
Na passagem dos dois períodos não haveria, portanto, a criação de termos novos, somente a mudança de significado deles. Logo, a origem das corporações modernas só poderia ser encontrada no direito pós clássico. ${ }^{157}$

Já para R. Orestano, o grande mérito da compilação pós clássica é exatamente o de submeter todas essas situações esparsas e tratadas de formas diversas ao longo do tempo, a uma disciplina, submetê-las a princípios comuns, tornando inevitáveis interpolações em alguns momentos. ${ }^{158}$

Essas situações foram tratadas, em sua maior parte, segundo o Autor, em três títulos diversos do Digesto: sob o ângulo processual em D. 3,4 (Quod cuiuscumque universitatis nomine vel contra eam agatur); sob o ângulo penal em D. 47,22 (De collegiis et corporibus) e sob o ângulo administrativo em D. 50,6 (De iure immunitatis).

Foi exatamente essa sistematização que permitiu a elaboração da doutrina medieval das universitates personarum e, posteriormente, da teoria da personalidade jurídica. $^{159}$

Por fim, R. Orestano conclui que o Direito Romano passou por quatro configurações para as situações unificadas, a saber, a concepção material (na qual se inclui a herança jacente) ou real, total, corporalística e abstrata. ${ }^{160}$

Essa primeira concepção foi a que mais durou, fazendo - se presente inclusive em época pós clássica, trabalhando com a noção objetiva de res, como centro de imputação, servindo tanto para unificações de base pessoal como patrimonial.

Na segunda, há a idéia de conjunto constituído de sua totalidade, com a característica de atomismo, geralmente com o uso de adjetivos como universi, omnes etc. Havia, porém, uma série de questões, como a da admissão de uma vontade totalitária ${ }^{161}$ que somente a próxima concepção poderia resolver.

No terceiro, o conjunto passa a ser encarado como uma unidade, aparecendo aqui a idéia de corpora ex distantibus, com o uso de substantivos coletivos, mas sem diferenciar essa unidade de seus elementos pois ela se identificava com eles.

Já a última concepção realiza a distinção entre o conjunto e seus elementos, tratando o primeiro de forma abstrata e independente.

R. Orestano ressalta que não há uma sucessão cronológica perfeita entre a segunda e a terceira concepção. Em vários momentos, elas se permeiam, e, para certas situações uma é aplicada e em outras não.

157 Cfr. ALBERTÁRIO, Emilio. op. cit., p. 120.

158 Cfr. ORESTANO, Riccardo. op. cit., p.176 e 177.

159 Id. Ibid., p.177 e 178.

160 Id. Ibid., p.178.

161 O Autor exemplifica com os seguintes fragmentos: Ulp. 49 ad ed., D. 38,3,1,1 e Paul. 54 ad ed., D. 41,2,1,22. 
É na mudança semântica do termo corpus, encontrada no famoso fragmento D. $3,4,7,1^{162}$, que se abre caminho para a concepção abstrata de universitas. ${ }^{163}$

Nesta evolução não linear se encerra, segundo o Autor, a principal discussão ao que ele denomina de problemática das pessoas jurídicas no Direito Romano. ${ }^{164}$

A separação entre a figura dos sócios e a da pessoa jurídica, principal característica deste instituto, em uma análise preliminar, parece estar presente também no Direito Romano.

Todavia, G. Impallomeni nos adverte que no âmbito das corporações, o sujeito das relações jurídicas seriam sempre os sócios com a única diferença de que seriam sujeitos não uti singuli (como pessoa física), mas uti universi, derivando deste fato a sujeição a normas especiais. ${ }^{165}$

Entretanto, não se pode ter certeza absoluta deste tipo de regulação, pois ora temos as fontes pondo em ressalto, por exemplo, a figura dos municipes e não do municipium, ora relevo é dado à figura da universitas, no que se refere à capacidade processual. Haveria aqui, crê o Autor, uma variação terminológica, daí a diversa regulação. ${ }^{166}$

Desta oscilação decorre que também seria incerto se na administração patrimonial da corporação haveria uma vontade própria da corporação, vontade própria e diversa da vontade comum dos sócios, pois substitui a vontade dos membros ou se seria 0 comum acordo destes o que prevaleceria. ${ }^{167}$ Aqui, para se diferenciar estas duas vontades, basta recorrer ao modelo idealizado por J. J. Rousseau, ${ }^{168}$ isto é, a vontade geral que não é a mesma e não se confunde com a vontade dos cidadãos.

Para S. Perozzi existem graus de personificação. Quando todas as situações jurídicas cujo protagonista seja o homem, puderem ser vivenciadas também pela pessoa jurídica, ter-se-á alcançado o grau máximo de personificação. O que não significa que os demais níveis não sejam também reconhecidos como pessoas jurídicas. ${ }^{169}$

Nas corporações, ora a lei se refere aos direitos e obrigações da corporação, ora ao de seus membros (tidos aqui como associação). Trabalha-se, pois, com a união do princípio unitário com o princípio associativo. ${ }^{170}$

\footnotetext{
162 Esse fragmento será analisado posteriormente.

163 Cfr. ORESTANO, Riccardo. op. cit., p. 183.

164 Id. Ibid., p. 184.

165 Cfr. IMPALLOMENI, Giambattista. op. cit., p. 1029 e 1030.

166 Id. Ibid., p. 1.029.

167 Id. lbid., p. 1.030.

168 Cfr. BETTI, Emilio. op. cit., p.209, nos explica esta idéia sustentando que o interesse coletivo não se confunde com o interesse público nem com a soma de interesses individuais.

169 Cfr. PEROZZI, Silvio. op. cit., p. 567.

170 Id. Ibid.
} 
Com o passar do tempo, afirma o Autor, observamos um preponderar do princípio corporativo sobre o associativo, todavia, a passagem do múltiplo para o unitário foi extremamente complexa na Antiguidade e ainda o é atualmente.

Assim, essa abstração só foi alcançada em idade avançada, por meio de uma lenta evolução, na qual os princípios associativo e corporativo se misturavam, sendo aplicados, por vezes, a uma mesma situação ao mesmo tempo. ${ }^{171}$

\section{A Passagem de Ulpiano e seu Desenvolvimento}

O fragmento D. $3,4,7,1$, do jurisconsulto Ulpiano foi a base para todo o desenvolvimento da teoria sobre a pessoa jurídica, exatamente por, a princípio, destacar de forma clara, a responsabilidade dos integrantes de uma corporação da responsabilidade do próprio ente ao qual pertenciam.

Vejamos a redação deste fragmento:

Ulp. 10 ad ed., D. 3,4,7,1. Si quid universitati debetur, singulis non debetur, nec quod debet universitas, singuli debent.

Se alguma coisa é devida à universalidade, não é ela devida a cada um [daqueles que a compõem]: nem aquilo que a universalidade deve, devem os seus componentes. $^{172}$

B. Albanese afirma que essa passagem demonstra que o Direito Romano tinha consciência da subjetividade jurídica autônoma das corporações. ${ }^{173}$

No mesmo sentido se posiciona P. Bonfante, ${ }^{174}$ para quem o Direito Romano reconhece a capacidade patrimonial, também chamada de ius commercium, a entes coletivos e fictícios, denominando estes entes de várias formas. Todavia, nenhuma delas seria adequada para caracterizar genericamente o que hoje denominamos pessoa jurídica. Nomes mais específicos seriam usados para esmiuçar os diversos tipos de corporações (universitas ou corpus) e fundações (piae causae).

A caracterização dessa personalidade jurídica se daria justamente com a atribuição de direitos e deveres à corporação e não a seus membros. ${ }^{175}$

\footnotetext{
Id. Ibid., p. 568.

172 Tradução livre.

173 Cfr. ALBANESE, Bernardo. op. cit., p. 181.

174 Cfr. BONFANTE, Pietro. op. cit., p.175.

175 Id. Ibid., p.176.
} 
É pacífica a opinião de que a diferenciação entre a figura da coletividade e seus componentes não estava presente no período pré clássico, pois exigiria uma capacidade de abstração não compatível com a realidade romana desta época. ${ }^{176}$

Sendo assim, no período pré-clássico, não há a concepção de um ente abstrato titular de direitos e obrigações. Se um patrimônio pertencesse a várias pessoas, cada uma delas era proprietária de uma parcela dos bens. O que havia era um condomínio, uma co-propriedade deste patrimônio (como no caso do patrimônio estatal, que, neste período, pertencia aos cidadãos). ${ }^{177}$

Já no direito clássico, há o reconhecimento das corporações, mas não o das fundações. O primeiro passo para isto foi a visão do Estado como algo abstrato, diverso dos cidadãos, o chamado Populus Romanus. ${ }^{178}$

Deste reconhecimento, consolida-se o princípio de que os membros de uma universitas são estranhos, ou seja, não pertencem às relações jurídicas cujo titular seja a própria universitas. ${ }^{179}$

Como consequência, o escravo de uma universitas poderá testemunhar contra ou a favor de seus membros, sendo que estes não terão direito de patronato sobre 0 escravo, caso ocorra manumissão. ${ }^{180} \mathrm{Um}$ fragmento de Marciano trata deste tema:

\begin{abstract}
Marc. 3 inst., D. 1,8,6,1. Universitatis sunt non singulorum veluti quae in civitatibus sunt theatra et stadia et similia et si qua alia sunt communia civitatium. Ideoque nec servus communis civitatis singulorum pro parte intellegitur, sed universitatis et ideo tam contra civem quam pro eo posse servum civitatis torqueri divi fratres rescripserunt. Ideo et libertus civitatis non habet necesse veniam edicti petere, si vocet in ius aliquem ex civibus.

São da universalidade e não dos indivíduos [que a compõem] aquelas coisas que nas cidades estão, como os teatros, estádios e similares, se aqueles outros são bens comuns das cidades. E por isso, o servo comum da cidade não é entendido como dos indivíduos, mas da universalidade e, por isso, respondem os Divinos Irmãos que tanto contra quanto a favor do cidadão pode o servo da cidade se pronunciar. E, desta forma, o liberto da cidade não tem a necessidade da permissão do edito para postular se chama a juízo algum dos cidadãos. ${ }^{181}$
\end{abstract}

\footnotetext{
176 GUARITA CARTAXO, Ernani. As Pessoas Juridicas em suas Origens Romanas, Evolução e Conceito. Curitiba: Paranaense, 1943. p.29.

177 Cfr. MOREIRA ALVES, José Carlos. op. cit., p. 41 e 142.

178 Id. Ibid., p. 142.

179 Cfr. IMPALLOMENI, Giambattista. op. cit., p.1030.

180 Id. Ibid., p. 1030.

181 Tradução livre.
} 
Outro efeito importante é o de que os créditos e débitos da pessoa jurídica não poderão ser cobrados pelos ou dos membros, logo a universitas responde com o próprio patrimônio. ${ }^{182}$

Isto caracteriza a responsabilidade limitada dos sócios. Todavia, existem entes imateriais com responsabilidade ilimitada, ou seja, sem personalidade jurídica. Tal vantagem, contudo, não favoreceu a multiplicação de sociedades, isto porque era pequena a existência de pequenos e médios sócios suficientes para formar um capital social consistente, além da preferência de alianças, por parte dos grandes capitalistas, já que, nas sociedades, nem todos podem mandar, entre outros motivos. ${ }^{183}$

Para A. Guarino, com a edição da Lex Iulia de collegiis, ${ }^{184}$ no início do período clássico, ${ }^{185}$ essa separação entre sócio e sociedade torna-se clara, pois há a dissolução da maioria das corporações existentes, sendo necessária, a partir de então, a autorização, do Imperador ou do Senado, para que novas corporações fossem fundadas ${ }^{186}$

Entretanto, alguns estudiosos não atribuem essa distinção ao período clássico. ${ }^{187}$

Como já ressaltado, de acordo com F. de Martino, todas as fontes do Digesto que usam o termo universitas para designar uma pluralidade de pessoas com capacidade jurídica diversa da dos seus membros não são de origem clássica, sendo fruto de interpolações. Isso seria demonstrado pelo edito pretório, que nunca se refere a universitas, mas sempre a municipium ou civitas. ${ }^{188}$

O termo corpus, principalmente em sua expressão corpus habere, também não significava uma capacidade jurídica diferenciada, podendo ser ou apenas um grupo

182 Cfr. IMPALLOMENI, Giambattista. op. cit., p. 1.030.

183 Cfr. GUARINO, Antonio. op. cit., p.308.

184 BETTI, Emilio. op. cit., p. 211-213, afirma que a diferença entre entes tolerados de fato e uma pessoa jurídica é sutil. Isto porque se trata de um ato positivo o conferimento da personalidade jurídica, pela qual o Estado cria um novo ente e o coloca dentro de seu ordenamento jurídico, seja no que diz respeito ao direito público, seja no que se refere ao direito privado. Já quanto à autorização dada pelo Estado a algumas associações, temos, na verdade, um ato negativo, administrativo, reconhecendo que a atividade da corporação é compatível com o interesse público, aqui, não haveria a intenção de criar um novo ente, mas apenas de satisfazer uma demanda social, permitindo a coexistência do Estado com outras coletividades que perseguem fins diversos. Cabe lembrar que, apesar do pressuposto da realidade social para que exista a pessoa jurídica, não é, ela própria, ainda o ente abstrato.

185 GUARITA CARTAXO, Ernani. op. cit., p.202, também atribui o fenômeno de separação entre a universitas e seus membros aos juristas clássicos.

186 Cfr. GUARINO, Antonio. op. cit., p.307.

187 CATALANO, Pierangelo. op. cit., p.48 50 sustenta que dizer que os juristas romanos adotaram a teoria da pessoa jurídica seria "fazer uma operação intelectual de leito de Procusto", pois os romanos ora salientaram o aspecto de pluralidade e ora o de unidade, conforme as necessidades dos homines organizados em associações. Desta forma, a idéia de unidade apresentada em D. 3,4,7,1 seria uma "rechtspolitische Notwendigkeit"

188 Persona Giuridica. NuovoDigesto Italiano. Torino: UTET, 1939. v. IX. p.931. 
de pessoas organizado, ou uma forma de organização social, ou, numa concepção técnica, uma associação de trabalhadores, sejam as voluntárias, sejam as obrigatórias. ${ }^{189}$

O Autor afirma então que um corpus poderia ser uma pessoa jurídica, mas também poderia não o ser. Logo, a idéia de pessoa jurídica como uma ficção seria desconhecida do Direito Romano.

Todavia, poderíamos ter em mente outras concepções e teorias da pessoa jurídica, logo, afirmar que não era presente a teoria da ficção, no Direito Romano, não significaria, necessariamente, a ausência deste instituto.

O único tipo de pessoa jurídica conhecido em época clássica seria a das corporações, como unidade distinta de seus membros, que poderiam variar sem extinguir ou transformar a corporação. ${ }^{190}$ Contudo, o Autor se contradiz ao reconhecer a existência independente das corporações na época clássica e afirmar serem interpolados quaisquer textos com o termo universitas, que representariam exatamente a diferenciação entre a corporação e seus membros.

Já M. Kaser é mais coerente, apesar de não admitir a origem clássica da distinção entre ente imaterial e seus integrantes.

Para esse Autor, ${ }^{191}$ a concepção de pessoa jurídica como sujeito de direito aliada com a sua capacidade jurídica, transformando-a em um ente diverso de seus membros, só se dá no século XIX.192

O que o Direito Romano teria percebido é que existem conjuntos de pessoas que possuem uma vontade coletiva, existindo um patrimônio diverso e que não poderia estar à livre disposição dos sócios. ${ }^{193}$

Todavia, essas corporações não seriam encaradas como entes distintos de seus membros, mas como uma pluralidade, globalidade de membros, sem destacar-se deles. ${ }^{194}$

Já para E. Albertário, esse fragmento seria interpolado.

Neste texto, segundo o Autor, Ulpiano ou não usava o termo universitas ou o usava com referência ao universo cives de uma civitas, mas nunca no sentido usual de ente diverso de seus integrantes. ${ }^{195}$

\footnotetext{
189 Id. Ibid.

190 Id. Ibid.

191 No mesmo sentido, CATALANO, Gaetano. Persona Giuridica - Diritto Intermedio. Novissimo Digesto Italiano. Torino: UTET, 1965. v. XII. p.1032.

192 Cfr. KASER, Max. op. cit., p.115 e 116.

193 Id. Ibid., p.116.

194 Id. Ibid.

195 Cfr. ALBERTÁRIO, Emilio. op. cit., p.111.
} 
Isso porque esse fragmento, integrante do livro 10 ad edictum, se insere, pois, no contexto dos seguintes fragmentos ${ }^{196}$ : D. 12,1,27; D. 15,4,4; D. 43,16,4; D. $50,16,15 .{ }^{197}$

Ulp. 10 ad ed., D. 12,1,27. Civitas mutui datione obligari potest, si ad utilitatem eius pecuniae versae sunt: alioquin ipsi soli qui contraxerunt, non civitas tenebuntur.

A cidade pode ser obrigada pela dação de mútuo, se em benefício dela foi vertido o dinheiro: em outro caso, só os próprios indivíduos que o contraíram [se obrigarão], não será suportado pela cidade [o mútuo]. ${ }^{198}$

Ulp. 10 ad ed., D. 15,4,4. Si iussu eius, qui administrationi rerum civitatis praepositus est, cum servo civitatis negotium contractum sit, Pomponius scribit quod iussu cum eo agi posse.

Se por ordem daquele, o qual foi encarregado da administração dos bens da cidade, como [no caso] de um negócio contratado por um servo, Pompônio escreve que se pode agir por mandato contra ele. ${ }^{199}$

Ulp. 10 ad ed., D. 43,16,4. Si vi me deiecerit quis nomine municipum, in municipes mihi interdictum reddendum Pomponius scribit, si quid ad eos pervenit.

Se por violência alguém foi desapossado por mim, em nome do município, aos munícipes contra mim deve ser dado interdito, escreve Pompônio, se isto os atingiu. ${ }^{200}$

Todos esses textos, inclusive o D. 3,4,7 e D. 3,4,7,2, se referem à civitas e ao municipium. Seria, aqui, portanto, espúrio o termo universitas, sendo o fragmento D. $3,4,7,1$ e D. $3,4,7,2$ interpolados, para que se construísse uma disciplina da universitas personarum. 201

Muito relevante para a análise deste fragmento é a observação do papel dos glosadores e sua influência no entendimento do Direito Romano e na posterior elaboração da teoria do ente moral.

Para E. Guarita Cartaxo, a última fase do desenvolvimento, no Direito Romano, da concepção abstrata de pessoa jurídica se dá com a criação da idéia da universitas, sendo

\footnotetext{
Id. Ibid.

Esse fragmento será reproduzido posteriormente.

198 Tradução livre.

199 Tradução livre.

200 Tradução livre.

201 Cfr. ALBERTÁRIO, Emilio. op. cit., p. 111.
} 
o Populus representado pela concepção unitária de Respublica e os municipes pela de municipium. ${ }^{202}$

A representação destes entes abstratos passa a ser diversa da representação dos indivíduos que o compõem. E, a partir daí, as pessoas jurídicas, essas associações, são equiparadas com a pessoa humana, no que se refere à sua capacidade de ser sujeito de relações jurídicas. ${ }^{203}$

Conforme G. Catalano, a permanência do esquema romano no que diz respeito às sociedades de direito privado seria de caráter duvidoso, pois o que se manteve foi a regulação quanto às organizações territoriais e das cidades, na qual a concepção romana manteve-se firme, havendo uma transformação dos vici romanos em comunidades rurais e burgos. ${ }^{204}$

Isso porque toda a disciplina romana sofreu uma grande influência da concepção germana que, apesar de reconhecer a propriedade coletiva e a liberdade de associação, não distinguia a sociedade, a associação dos indivíduos que as integrava. ${ }^{205}$

Esse é o motivo pelo qual E. Guarita Cartaxo afirma que a concepção de que, no Direito Romano, a pessoa jurídica era uma ficção é equivocada, pois essa teoria só se deu no período medieval. ${ }^{206}$

Esse equívoco seria obra dos glosadores os quais, segundo o Autor, não souberam bem compreender a doutrina romana pois, influenciados pelos princípios corporativos germânicos, desvirtuaram o verdadeiro conceito de universitas. ${ }^{207}$

$\mathrm{O}$ conceito de corpus é equiparado ao corpo humano e comparado à universitas, resultando na impossibilidade de um afastamento real do conceito unitário de seus componentes. ${ }^{208}$

Os glosadores, ao se depararem com as concepções romanas de corpus e universitas, perceberam que estavam diante de um fenômeno desconhecido e resolveram adaptar à sua realidade esses conceitos.

Desta forma, a concepção germânica era a de que as corporações nada mais eram que o conjunto de seus membros e que, sendo assim, os bens das corporações

\footnotetext{
Cfr. GUARITA CARTAXO, Ernani. op. cit., p.50.

Id. Ibid., p.51.

Cfr. CATALANO, Gaetano. op. cit., p. 1.033.

Id. Ibid.

206 Cfr. GUARITA CARTAXO, Ernani. op. cit., p. 177.

207 Id. Ibid., p. 177 e 178.

208 Id. Ibid., p.178, o que se demonstraria com a glosa ao fragmento C. 2, 14,1.
} 
eram vistos como de propriedade indivisa de seus componentes, conceito esse totalmente oposto ao romano ${ }^{209}$, no qual há clara distinção entre a universitas e seus integrantes. ${ }^{210}$

Sendo assim, afirma o Autor, quanto à responsabilidade dos membros de uma associação, foi estabelecido, pelos glosadores, o princípio da subsidiaridade, mesclando os princípios germânicos e a idéia romana.

Já no que se refere à vontade da universitas, os glosadores estabeleceram que havia uma dificuldade de fato para a expressão de sua vontade, isso porque se confundia o ente ideal com os seus membros na doutrina realista germânica, desta forma, a solução a ser adotada foi a de exigir não a unanimidade, mas a maioria de votos para uma decisão. ${ }^{211}$

Outra questão que deriva da idéia de pluralidade real é a regra de que quando extinta a corporação, haverá a divisão do patrimônio desta entre os seus membros. Todavia, essa regra é derivada da afirmação de Marciano, em D. 47,22,3, que só era aplicável aos colégios ilícitos. ${ }^{212}$

Marc. 2 iudic. public., D. 47,22,3. Collegia si qua fuerint illicita, mandatis et constitutionibus et senatus consultis dissolvuntur: sed permittitur eis, cum dissolvuntur, pecunias communes si quas habent dividere pecuniamque inter se partiri.

Se colégios forem ilícitos, serão eles dissolvidos por mandados e constituições e senatosconsultos. No entanto, é permitido àqueles que são dissolvidos e que possuem riquezas comuns dividí-las entre si e repartir o dinheiro. ${ }^{213}$

Entretanto, para doutrinadores como P. S. Leicht, os glosadores, apesar da influência germânica, não adotaram uma postura que fosse contra a natureza da distinção realizada pelo fragmento de Ulpiano e, embasam a sua tese na análise dos bens públicos.

Há, pois, uma dificuldade por parte dos glosadores em definir os bens que são ou não de uso público, problema que também surge nas fontes romanas. ${ }^{214}$

209 CATALANO, Gaetano. op. cit., p.1033, compartilha da mesma opinião ao afirmar que a primeira tentativa de sistematização do assunto foi feita pelos glosadores que, dentre as diversas concepções apresentadas na obra de Justiniano, escolheram a coletivista, concebendo uma idéia de quota de cada sócio sobre os bens da sociedade, além de uma responsabilidade subsidiária destes pelas dívidas daquela, o que seria contraditório com o princípio quod universitas est non est singulorum, reconhecendo a capacidade da sociedade de estabelecer relações jurídicas e inclusive de cometer delitos, não se separando a figura da universitas e da societates.

210 Cfr. GUARITA CARTAXO, Ernani. op. cit., p. 179.

211 Id. Ibid., p. 180.

212 Id. Ibid., p.181.

213 Tradução livre.

214 LEICHT, Pier Silverio.Ricerche sulla responsabilità del comune in caso di danno - Contribuzione alla storia dell'università medievale. Scritti Vari di Storia del Diritto Italiano. Milano: Giuffrè, 1943. v. 1. p.32. 
Ter-se-ia a afirmação de que a universitas não possuía a propriedade de bens públicos, mas somente o uso. Isso porque o termo universitas se referiria ao conjunto de cidadãos que usam esses bens públicos, como as ruas e os teatros e o termo nullius se referiria ao ente abstrato ao qual se atribui a propriedade destes bens, não sendo, todavia, ainda bem definido ${ }^{215}$. O fragmento D. 1,8,1, de Gaio comprovaria isto:

Gai. 2 inst., D. 1,8,1. Summa rerum divisio in duos articulos deducitur: nam aliae sunt divini iuris, aliae humani. Divini iuris sunt veluti res sacrae et religiosae. Sanctae quoque res, veluti muri et portae, quodammodo divini iuris sunt. Quod autem divini iuris est, id nullius in bonis est: id vero, quod humani iuris est, plerumque alicuius in bonis est, potest autem et nullius in bonis esse: nam res hereditariae, antequam aliquis heres existat, nullius in bonis sunt. Hae autem res, quae humani iuris sunt, aut publicae aut privatae. Quae publicae sunt, nullius in bonis esse creduntur, ipsius enim universitatis esse creduntur: privatae autem sunt, quae singulorum sunt.

A principal divisão das coisas se reduz a duas seções: efetivamente, umas são de direito divino, outras [de direito] profano. De direito divino são, por exemplo, as coisas sacras e religiosas. Também as coisas santas, como os muros e portas, são, de certa maneira, de direito divino. Porém, aquilo que de direito divino é, nos bens de ninguém está. No entanto, é verdade que aquilo que de direito humano é, geralmente nos bens de alguém está. Entretanto, pode também nos bens de ninguém estar: de fato, os bens hereditários, antes que qualquer herdeiro exista, estão nos bens de ninguém. Além disso, aquelas coisas as quais são de direito profano, ou públicas ou privadas [são]. Aquelas que são públicas, nos bens de ninguém são confiadas, na verdade, foram deixadas nos bens da própria universalidade. Já aquelas que são privadas, dos indivíduos são. ${ }^{216}$

Já para outros autores, haveria dois tipos de bens públicos, aqueles usados pelos cidadãos, que usam destes bens individualmente, não como coletividade (que seriam do domínio e uso da cidade como os teatros e ruas) e aqueles usados pela cidade, que poderia, por exemplo, alugá-los (que seriam do domínio e fruto da cidade como os servos e terrenos) e, desta forma, as res nullius seriam de propriedade da universitas. ${ }^{217}$

\footnotetext{
LEICHT, Pier Silverio.op cit.

6 Tradução livre.

217 Cfr. LEICHT, Pier Silverio. op. cit., p.33.
} 
Também nesta hipótese, o Autor crê que haja somente uma reprodução das fontes (D. 50,16,15), usando-se o termo civitas em dupla acepção, que equivaleria ao que hoje chamamos de bens públicos e bens de uso público. ${ }^{218}$

Ulp. 10 aded., D. 50,16,15. Bona civitatis abusive "publica" dicta sunt: sola enim ea publica sunt, quae populi Romani sunt.

Os bens da cidade foram abusivamente chamados de públicos: na verdade só são públicos aqueles que são do povo romano. ${ }^{219}$

A glosa de D. 3,4,7,1 demonstra, portanto, como a nítida separação do patrimônio do sócio e o da sociedade era claro em época medieval, apesar de opiniões de sentido contrário.

Todavia, em alguns momentos afirma-se que os credores dos membros da universitas poderão agir contra o patrimônio desta. Neste caso, para o Autor, a palavra universitas se refere aos membros da comunidade e não ao ente, pois aqui se fala do uso e não da propriedade, dando aos credores o direito de usar o que era reservado a esses membros. ${ }^{220}$

Em outros momentos, acusa-se de haver uma influência germânica na teoria dos glosadores, principalmente na hipótese em que a comunidade não tinha como pagar as suas dívidas e colhia de seus membros o dinheiro necessário para pagá-las. Entretanto, isso não atingiria a natureza universitária. ${ }^{221}$

Até porque essa exigência de contribuição advém do pacto que está por base da universitas, ou seja, de um juramento feito pelos cidadãos de contribuir para o pagamento de despesas públicas. ${ }^{222}$

Sendo assim, essa cobrança dos indivíduos tem sempre por base, na teoria dos glosadores, o pacto e a constituição da universitas, não contrariando, portanto, sua natureza de ente diverso dos seus membros.

Pactos especiais existiam permitindo que pelas dívidas da cidade respondesse o cidadão, mas esses eram pactos especiais e o cidadão se responsabilizava individualmente e não devido à sua qualidade de cidadão, tanto que se alguém desejar sair da universitas deverá deixar garantia da parte do débito comunitário que lhe cabe. ${ }^{23}$

\footnotetext{
218 LEICHT, Pier Silverio.Ricerche sulla responsabilità del comune in caso di danno - Contribuzione alla storia dell'università medievale. Scritti Vari di Storia del Diritto Italiano. Milano: Giuffrè, 1943. v. 1.

219 Tradução livre.

220 Cfr. LEICHT, Pier Silverio. op. cit., p. 33.

221 Id. Ibid., p. 34.

222 Id. Ibid.

223 Id. Ibid., p. 34-35.
} 
Assim, todos esses fatos, tendo-se em conta que nunca há uma preponderância do indivíduo sobre a universitas, em nada modificam a natureza abstrata deste ente.

G. Voet resume a situação no período romano da seguinte forma: para que os membros de uma comunidade sejam obrigados a saldar um débito, é necessário, a princípio, que o assumam em nome próprio e no da própria comunidade. Neste caso, a responsabilidade será solidária, havendo direito de reembolso por parte dos cidadãos. ${ }^{224}$

Entretanto, na hipótese da dívida ser contraída somente em nome da comunidade, cada cidadão será responsável parcialmente pela solução do débito, já que eles possuem o dever de colaborar com a comunidade. Mas é necessário observar que esse dever só surge quando a dívida for contraída em manifesto interesse público. ${ }^{225}$

Caso não fosse claro, mesmo que não completamente, na mente dos glosadores a diferença entre comunidade e cidadãos, não se entenderia o fato da plena capacidade dos cidadãos com a diminutio capitis das civitas. ${ }^{226}$

Há ainda a questão dos glosadores que admitem que uma universitas tenha capacidade de agir com dolo. Entretanto, o Digesto claramente não admite esta hipótese, apesar de alguns glosadores a admitirem e ainda responsabilizarem os administradores da universitas. 227

Por isso, vemos um desvio da doutrina medieval em relação à romana, isso porque há uma confusão, por parte dos glosadores entre o campo público e privado, típico de uma sociedade feudal.

Assim, no caso de responsabilidade das comunidades, há inevitavelmente uma confusão entre os indivíduos e o corpus. ${ }^{228}$

No entanto, de acordo com E. Guarita Cartaxo, é o Direito Canônico que retoma a disciplina romana de separação entre o ente ideal e seus membros, afirmando a identidade daquele quando da mudança destes. Essa unidade ideal estaria a serviço de certas finalidades e ainda sofreria, em menor grau, restrições provenientes das concepções germânicas. Um exemplo disso é o direito conferido aos membros da Igreja de utilizar o patrimônio desta, o que fere a nítida distinção entre corporação e seus integrantes. ${ }^{229}$

Portanto, as raizes da teoria moderna da personalidade jurídica encontramse em época medieval, sobretudo no séc. XIV, quando os juristas, em uma incipiente base canônica, unem elementos do Direito Romano, do Direito Romano - Canônico, do Direito

\footnotetext{
224 VOET, Giovanni. Commento alle Pandecte. Veneza: Pietro Naratovich, 1846. v. 1, p. 479.

225 Id. Ibid., p. 480.

226 Cfr. LEICHT, Pier Silverio. op. cit., p. 36.

227 Id. Ibid., p. 36 e 37.

228 Id. Ibid., p. 39.

229 Cfr. GUARITA CARTAXO, Ernani. op. cit., p. 182.
} 
Germânico e consuetudinário para montar um ser ficto, um, nas palavras de G. Catalano, mero nomen iuris, que configuraria o que hoje chamamos de pessoa jurídica. ${ }^{230}$

É certo, pois que os traços da disciplina da personalidade jurídica romana foram dissipados no período medieval. No entanto, a Igreja não desejava perder os privilégios reconhecidos pelo Direito Romano-Teodosiano, isto é, a possibilidade de possuir, receber legados e heranças, enfim, de adquirir propriedade. ${ }^{231}$

Neste momento, começa-se a utilizar o termo persona para designar estes entes ideais, que possuem um corpus e, portanto, subjetividade jurídica. Essa utilização tem como origem a comparação feita, nas fontes romanas, entre as unidades ideais e o homem. Analisando a concepção cristã de homem, essa comparação era de cunho metafórico ou ficcional. ${ }^{232}$

Com Sinibaldo de Fieschi, aparece a expressão universitas fingatur esse una persona e se faz a diferenciação entre associações necessárias e voluntárias e associações reais (de caráter institucional e público) e pessoais (de direito privado). ${ }^{233}$

É a partir desta construção canônica que surge a teoria da ficção, já que a relação entre essas situações unificadas e o homem só poderia ser de caráter figurado.234

Nos séculos XIII e XIV, temos o surgimento dos pós glosadores, cujo maior expoente é Bartolo de Sassoferrato, que substituem as primeiras glosas do Digesto por suas próprias doutrinas, procurando, de uma forma ou de outra, ampará-las nos textos romanos. $^{235}$

Neste período, ressalta-se ainda mais a teoria da ficção e a vagueza do conceito de universitas. Há uma correlação entre a pessoa fictícia à idéia germânica de corporação como a soma de seus membros. ${ }^{236}$

Apesar deste desenvolvimento, tempos depois, as concepções germânicas voltam a exercer influência e a identificação da pessoa jurídica com a totalidade de seus membros permite afirmar que ela atue com dolo ou que tenha animus possidenti ou que seja acusada criminalmente. ${ }^{237}$

Há um convívio entre idéias germânicas e romanas, daí a presença de regras contraditórias como a da responsabilidade pessoal dos membros da pessoa ficta e a concessão da propriedade desta aos seus integrantes. ${ }^{238}$

\footnotetext{
Cfr. CATALANO, Gaetano. op. cit., p. 1.032.

Id. Ibid., p. 1.033.

Cfr. GUARITA CARTAXO, Ernani. op. cit., p. 182.

233 Cfr. CATALANO, Gaetano. op. cit., p. 1.034.

234 Cfr. GUARITA CARTAXO, Ernani. op. cit., p. 183.

235 Id. Ibid., p. 186.

236 Id. Ibid., p. 187.

237 Cfr. CATALANO, Gaetano. op. cit., p. 1.034.

238 Cfr. GUARITA CARTAXO, Ernani. op. cit., p. 188.
} 
Outros problemas aparecem. Retoma-se o argumento dos glosadores de que as fontes romanas indicam não uma impossibilidade, mas uma dificuldade de consentimento das pessoas jurídicas. ${ }^{239}$

As inovações quanto ao tema ficam estagnadas nos séculos XVI, XVII e XVIII, reconhecendo-se somente o caráter perpétuo das associações e havendo uma maior vigilância e controle sobre as aquisições e alienações das sociedades, principalmente das pertencentes à Igreja, gerando vários conflitos jurisdicionais. ${ }^{240}$

Neste período, não era feita uma distinção entre corporações, associações e fundações, nem mesmo entre pessoas jurídicas de direito público e privado, fato que teve reflexo, inclusive, no Código Napoleônico. ${ }^{241}$

É importante observar que, nas leis do Reino da Itália e também no código de 1865 a expressão ente moral não se referia a todos os tipos de pessoa jurídica, excluindose desta denominação as sociedades. ${ }^{242}$

Com a obra de R. Saleilles e F. Ferrara, percebe-se esta mescla feita desde o período dos glosadores e chega-se à conclusão de que não é romana a teoria da ficção, ao contrário do que afirma F. K. Savigny, teoria que hoje prevalece, mas que sofre problemas, cujo principal sintoma é a desconsideração da personalidade jurídica. ${ }^{243}$

Não houve, no Direito Romano, o desenvolvimento de nenhuma teoria acerca da personalidade jurídica. O que se fez presente foi a consciência de que a universitas emanava de um conjunto de pessoas, mas que não se confundia com elas, sendo inevitável a comparação, presente nas fontes, deste ente ideal com a pessoa humana. ${ }^{244}$

Consiste, para E. Guarita Cartaxo, num equívoco a afirmação de que os textos romanos apresentavam a universitas como um ente artificial, criado pelo legislador e, portanto, ficcional. O que há é a mera analogia, percebendo-se que os entes morais faziam as vezes de uma pessoa natural, ou que agiam como ela. ${ }^{245}$

$\mathrm{Na}$ verdade, essa insistente comparação entre universitas e o homem, que era até então o único sujeito de direito, tem função apenas ilustrativa, para concretizar um conceito abstrato, já que os romanos zelavam pela concretude de seus conceitos. ${ }^{246}$

\footnotetext{
GUARITA CARTAXO, Ernani. op. cit.

${ }^{240}$ Cfr. CATALANO, Gaetano. op. cit., p. 1.035.

${ }^{243}$ Cfr. GUARITA CARTAXO, Enani. op. cit., p. 190.

244 Id. Ibid., p. 190 e 191.

245 Id. Ibid., p. 191.

246 Id. Ibid., p. 195 e 196.
}

241 Id. Ibid.

242 Id. Ibid. 


\section{O que há é uma constatação de que o corpus é algo diverso de seus membros e não uma elaboração teórica, como querem alguns romanistas. ${ }^{247}$}

247 ELIACHEVITCH, Basile. op. cit., p. 350-373, nos apresenta uma comparação entre a concepção de pessoa jurídica no Direito Romano e as teorias atuais acerca destes entes abstratos. Para o Autor, a idéia de personalidade jurídica romana era relativamente simples e independente da estrutura interna da associação a qual se aplicava. Seu nascimento se deu juntamente com a idéia de autonomia municipal, já que os municípios tinham bens para realizar os objetivos a eles conferidos pelo Estado e a personalidade jurídica foi o instrumento pelo qual esses entes ingressaram no comércio jurídico. Já no que se refere aos colégios, a sua existência é muito anterior ao aparecimento da personalidade jurídica e dos municípios, apesar de possuírem bens, em confronto com terceiros, esses bens seriam co-propriedade dos integrantes do colégio e, se eles não bastassem, os bens individuais dos membros respondiam pelas dívidas. A personalidade jurídica vem exatamente para facilitar a inserção no comércio jurídico, harmonizando as relações interiores e exteriores do colégio, dispensando a atuação de todos os membros nos atos praticados, permitindo que colégios com muitos integrantes surgissem, facilitando a mudança deles entre si e, pois, contribuindo para a durabilidade do grupo. O mesmo se pode dizer das sociedades dos publicanos. Apesar de estruturas diferentes, podemos identificar pontos comuns acerca da personalidade jurídica, a saber, organização e patrimônio destinado a um objetivo comum.Todavia, a personalidade jurídica em nada alterava as relações internas dos membros, nem as relações patrimoniais deles com os bens da associação, seja dos colégios, das sociedades ou dos municípios. É importante a consideração do Autor no sentido de que não há expropriação dos membros do agrupamento a favor de outro ente, o que se diferencia da doutrina moderna. $O$ desenvolvimento posterior fez com que qualquer agrupamento fosse dotado de personalidade jurídica e, em alguns, para que isto ocorra, basta a declaração no estatuto. Coloca-se a pessoa jurídica, modernamente, como uma segunda categoria de sujeito de direitos. Isso não acontecia em Roma, pois, para os romanos, o único sujeito de direitos era o homem, no caso, os munícipes e os membros do colégio. A procura do sujeito de direito na universitas fez com que os glosadores opusessem a coletividade e os indivíduos, ao mesmo tempo em que diziam que a coletividade não era nada mais que os membros que a compõem. É com a Igreja e com a idéia de Igreja universal que repele qualquer direito dos membros sobre seus bens que se desenvolve essa concepção de pessoa jurídica, a qual atua ao lado dos indivíduos, pessoas físicas. Daí surge a colocação da pessoa jurídica como ser imaginário ou mero nomen iuris, conforme Baldus de Ubaldis. Mas, ainda na Idade Média, a colocação da pessoa jurídica era apenas com a finalidade de contrapor a coletividade e seus membros. É com Friedrich Karl Savigny que a teoria da ficção (preponderante até o séc. XIX), pois cria esses sujeitos de direito, toma forma e se coloca, definitivamente, a pessoa jurídica em grau de igualdade com o homem. Muitas teorias se opuseram à teoria da fiç̧ão, como a teoria da realidade (majoritária até o séc. XX), de base germânica, na qual a pessoa jurídica é uma realidade com vontade própria independente dos indivíduos que a compõem, desenvolvida, principalmente por Otto von Gierke, que, de certa forma reforça a idéia de Friedrich Karl Savigny na qual as pessoas jurídicas estão lado a lado com o homem, pois não seriam meras ficções, mas reais. Há, portanto, uma mudança brusca da concepção romana acerca da personalidade jurídica. Surgem então, teorias que atacam a noção de direito subjetivo e negam a existência da pessoa jurídica, como a tese de Bernhard Windscheid, para quem, os direitos da pessoa jurídica são, na verdade, direitos sem sujeitos. Outros desenvolveram essa base e disseram que não há pessoa, mas um objetivo (Alois von Brinz), um patrimônio de afetação. Rudolf von Jhering, com a sua visão sobre direito subjetivo como interesse juridicamente protegido, chega à conclusão de que são os membros das pessoas jurídicas e os destinatários das fundações os sujeitos de direito. No entanto, todas essas teorias negadoras da pessoa jurídica tratam o patrimônio delas como uma unidade que é regulada da mesma forma que o patrimônio de um indivíduo. Isso significa que esses autores negam a pessoa jurídica, mas não a personalidade jurídica, tal como concebida pelo Direito Romano. A teoria da fiç̧ão, para o Autor, não levou em consideração que a personalidade jurídica dos romanos não alterava a relação dos membros entre si, o que acarreta na ignorância das realidades jurídicas, pois o único ponto de união entre todos os diferentes grupos que possuem personalidade jurídica é a capacidade civil de estarem em comércio. Desta forma, a teoria da realidade objetiva se aproximaria da concepção romana ao permitir a coexistência da propriedade individual (que estava sob uma mão comum, apresentando-se a corporação como pluralidade diante de terceiros) de cada membro com a personalidade jurídica da corporação. No entanto, essas teorias admitem essa realidade no 
Haveria uma comparação e não a idéia de que o ente ideal seria uma pessoa de verdade, por ficção. ${ }^{248}$

\section{Conclusão}

Percebemos, pois, que o Direito Romano também teve de lidar com situações as quais hoje são resolvidas pela aplicação do instituto da pessoa jurídica. Todavia, para que as demandas sociais fossem atendidas, não houve a necessidade de se criar ficcionalmente um ente e considerá-lo como pessoa, tal como o homem.

Consoante a sistemática romana, não há a elaboração de uma teoria pelos jurisconsultos, o que, por si, não significa que, de fato, tal instituto não se fez presente na realidade da época.

E é exatamente esta característica da sociedade romana que fez com que a pessoa jurídica não fosse por ela concebida como um único conceito, uma moldura na qual todas as situações apresentadas teriam de se encaixar.

O que temos são graus de personificação, coletividades com maior ou menor capacidade jurídica dependendo do fim a que se destinassem e de suas características particulares. E é por isso que se afirma a não sobreposição de um período sobre o outro, mas a sua complementaridade ao longo do tempo.

direito germânico, não no Direito Romano. O único ponto de divergência entre essas teorias e a concepção romana seria o fato de que as corporações nunca foram sujeitos de direito, seja de forma ficta, seja de forma real. Temos também a teoria da escola de direito público, a qual sustenta que o direito subjetivo, ou a capacidade de agir não é inato do ser humano, sendo a ele conferida pelo direito, assim como o direito pode conferir essa capacidade às coletividades. Sendo assim, nessa corrente, o direito precisa de pontos de aplicação de direitos e obrigações. Quando esse ponto não for a pessoa física, temos a pessoa jurídica. Neste contexto aparece a separação entre a personalidade jurídica e a coletividade, que é a premissa para que a personalidade exista. Essa separação foi aperfeiçoada por Joseph Octave Léon Michoud, para quem a pessoa jurídica é somente um conceito jurídico, uma ferramenta, pois a sociedade pode atribuir direitos não só a pessoas reais, mas a coletividades ou objetivos ideais. Sendo assim, essa teoria bate com a teoria romana, mostrando que as pessoas jurídicas são apenas realidades de direito e que basta a atribuição da capacidade de estar em juízo e da de adquirir direitos e obrigações para que possamos falar em pessoa jurídica. O ponto em comum de todas essas teorias se dá com a relação entre personalidade jurídica e sujeito de direito. Todavia, esse relacionamento não é indispensável, na visão do Autor. Para o Autor, a personalidade jurídica é capacidade de ser um ponto de referência de direitos e obrigações, sendo que os organismos dotados dessa qualidade serão tratados da mesma forma que o homem no comércio jurídico. É necessário notar que a personalidade jurídica só se refere às relações com terceiros, sendo um instrumento que permite o tratamento como unidade no comércio e que unifica diversas estruturas que diferem entre si. Maurice Hauriou separa a personalidade jurídica da personalidade moral. Isso é importante, pois a personalidade jurídica passa a ser o sujeito como capaz de se relacionar com terceiros, daí ser sujeito de direitos. Essa teoria traz a vantagem de conferir independência à personalidade jurídica, rompendo seu vínculo com a estrutura do organismo a que se aplica.

248 Cfr. GUARITA CARTAXO, Ernani. op. cit,, p.201. Mais uma vez, temos a aproximação da concepção romana com a teoria da realidade, já que os romanos, assim como os filiados a esta teoria, trabalhavam não com a forma, mas com o conceito de fenômeno real. 
A concepção abstrata destas situações unificadas, como vimos, não existia na época pré clássica, desenvolvendo-se no período clássico, por meio da idéia de corpora ex distantibus, passando para a de res incorporales e, finalmente, alcançando a noção de universitas, por meio da alteração do significado do termo corpus, que se evidencia no fragmento de Ulpiano D.3,4,7,1.

Enfim, o Direito Romano chegou a conceber a visão abstrata que hoje temos dos entes morais, porém, desapegados a construções teóricas, não consideravam a pessoa jurídica como um ser absoluto, de existência própria ou ficcional, apenas apresentavam ferramentas para suprir as demandas e objetivos que lhes eram convenientes. Quando a concepção abstrata não era conveniente, simplesmente a afastavam.

É nesse ponto que deveríamos nos espelhar no Direito Romano. Impregnado por conceitos e teorias que devem existir a qualquer custo, o jurista moderno tem dificuldades de lidar com incoerências próprias de um ente que não existe na vida real. ${ }^{249}$ Esse é o motivo pelo qual se fala sobre a crise da pessoa jurídica.

Entretanto, essa crise foi criada pela própria doutrina e a dificuldade de sua superação estará presente até que nos libertemos de um emaranhado teórico que há anos vem condicionando o pensamento jurídico.

São Paulo, outubro de 2010.

Referências

ALBANESE, Bernardo. Persona (storia), Diritto Romano. Enciclopedia del Diritto. Milano: Giuffrè, 1983. v. XXXIII.

ALBERTÁRIO, Emilio. Corpus e universitas nella designazione della persona giuridica. Studi Albertario. Milano: Giuffrè, 1933. v. 1.

ARANGIO-RUIZ, Vicenzo. Istituzioni di Diritto Romano. Napoli: Jovene, 2006.

BETTI, Emilio. Corso di Istituzioni di Diritto Romano. Milano: CEDAM, 1928. v. 1.

BIONDI, Biondo. La Dottrina Giuridica della Universitas nelle Fonti Romane. Bullettino dell' 'stituto di Diritto Romano Vittorio Scialoja. Milano: Giuffrè, 1958. v.XX.

BONFANTE, Pietro. Diritto Romano. Milano: Giuffrè, 1976.

249 Daí a afirmação de GALGANO, Francesco. Delle Persone Giuridiche. Bologna: Nicola Zanichelli, 1969. p.37 - 54, que, tratando sobre a questão do levantamento do véu da pessoa jurídica, diz claramente que esse véu nunca existiu, devendo o problema ser analisado do ponto de vista de que a limitação da responsabilidade dos integrantes de uma sociedade não passa de um privilégio legal, pois o Estado deseja incentivar o investimento em instituições de longo prazo. 
CATALANO, Gaetano. Persona Giuridica Diritto Intermedio. Novissimo Digesto Italiano. Torino: UTET, 1965. v. XII.

CATALANO, Pierangelo. As raizes do problema da pessoa jurídica. Revista de Direito Civil, Imobiliário e Empresarial. São Paulo: RT, 1995. v.73.

D'ALESSANDRO, Floriano. Persone Giuridiche e analisi del linguaggio. Padova: CEDAM, 1989. DE MARTINO, Francesco. Persona Giuridica. Nuovo Digesto Italiano. Torino: UTET, 1939. v. IX. DE ROBERTIS, Francesco M. Il Diritto Associativo Romano. Bari: Laterza \& Figli, 1938.

ELIACHEVITCH, Basile. La Personnalité Juridique em Droit Privé Romain. Paris: Sirey, 1942.

GALGANO, Francesco. Delle Persone Giuridiche. Bologna: Nicola Zanichelli, 1969.

GUARINO, Antonio. Diritto Privato Romano. 12. ed. Napoli: Jovene, 2001.

GUARITA CARTAXO, Ernani. As Pessoas Juridicas em suas Origens Romanas, Evolução e Conceito. Curitiba: Paranaense, 1943.

IMPALLOMENI, Giambattista. Persona Giuridica - Diritto Romano. Novissimo Digesto Italiano. Torino: UTET, 1965. v.XII.

KASER, Max. Römisches Privatrecht. Tradução portuguesa de S. Rodrigues e F. Hämmerle. Lisboa: Calouste Gulbenkian, 1999.

LAMARTINE CORRÊA DE OLIVEIRA, José, A Dupla Crise da Pessoa Jurídica. São Paulo: Saraiva, 1979.

LEICHT, Pier Silverio. Ricerche sulla responsabilità del comune in caso di danno - Contribuzione alla storia dell'università medievale. Scritti Vari di Storia del Diritto Italiano. Milano: Giuffrè, 1943, v. 1.

MARKY, Thomas, Curso Elementar de Direito Romano. São Paulo: Saraiva, 1995.

MAURO, Tommaso. La Personalità Giuridica degli Enti Ecclesiastici. Roma: Poliglota Vaticana, 1945.

MOREIRA ALVES, José Carlos. Direito Romano. Rio de Janeiro: Borsoi, 1967. v.1.

ORESTANO, Riccardo. Il Problema delle Persone Giuridiche in Diritto Romano. Torino: G. Giappichelli, 1968.

PEROZZI, Silvio. Istituzioni di Diritto Romano. Roma: Atheneum, 1928. v.1.

PUGLIESE, Giovanni. Res corporales, res incorporales e il problema del diritto soggetivo. Scritti giuridici scelti. Napoli: Jovene, 1985. v.III.

TALAMANCA, Mario. Istituzioni di Diritto Romano. Milano: Giuffrè, 1990.

VOCI, Pasquale. Piccolo Manuale di Diritto Romano. Milano: Giuffrè, 1979. v.1. 
VOET, Giovanni. Commento alle Pandette. Veneza: Pietro Naratovich, 1846. v.1.

VOLTERRA, Eduardo. Istituzioni di Diritto Privato Romano. Tradução espanhola de J. Daza Martinez. Madrid: Civitas, 1991. 